\title{
Soil nitrogen status as a regulator of carbon substrate flows through microbial communities with elevated $\mathrm{CO}_{2}$
}

\author{
Susan E. Ziegler ${ }^{1}$ and Sharon A. Billings ${ }^{2}$ \\ Received 20 May 2010; revised 5 November 2010; accepted 17 November 2010; published 4 February 2011.
}

[1] To assess how microbial processing of organic $\mathrm{C}$ inputs to forest soils may be influenced by elevated $\mathrm{CO}_{2}$ and altered $\mathrm{N}$ dynamics, we followed the fate of ${ }^{13} \mathrm{C}$-labeled substrates in soils from the Duke Free Air Carbon Enrichment site where differences in soil $\mathrm{N}$ status have been imposed by 7 years of $\mathrm{N}$ amendments. Heterotrophic respiration and $\delta^{13} \mathrm{C}$ of respired $\mathrm{CO}_{2}-\mathrm{C}$ and phospholipid fatty acids (PLFA) were measured to track activities of microbial groups and estimate a relative measure of substrate use efficiency (PLFA-based SUE). Results indicate an increased proportion of fungal and actinomycete activity in elevated $\mathrm{CO}_{2}$ soils, which varied with substrate. The negative effect of $\mathrm{N}$ on vanillin phenolic-C incorporation into actinomycete PLFA suggests legacies of fertilization can mitigate increased $\mathrm{C}$ flow into actinomycetes with elevated $\mathrm{CO}_{2}$. Further, the fourfold increase in PLFA-based SUE for vanillin phenolic-C in elevated $\mathrm{CO}_{2}$ soils that received $\mathrm{N}$ suggests future enhanced $\mathrm{N}$ limitation in elevated $\mathrm{CO}_{2}$ soils may promote enhanced respiratory loss relative to incorporation of some $\mathrm{C}$-substrates into microbial biomass. These short-term incubations did not reveal greater loss of soil organic carbon via respiration or shifts in SUE with elevated $\mathrm{CO}_{2}$. However, observed relative increases in activity of actinomycetes and fungi with elevated $\mathrm{CO}_{2}$ and mitigation of this effect on actinomycetes with $\mathrm{N}$ amendments suggests that elevated $\mathrm{CO}_{2}$ and predicted $\mathrm{N}$ limitation may alter the fate of slow-turnover soil organic matter (SOM) in two competing ways. Investigations need to focus on how these microorganisms may increase slow-turnover substrate use while possibly enhancing the prevalence of microbial cell wall structures that can serve as precursors of stabilized SOM.

Citation: Ziegler, S. E., and S. A. Billings (2011), Soil nitrogen status as a regulator of carbon substrate flows through microbial communities with elevated $\mathrm{CO}_{2}$, J. Geophys. Res., 116, G01011, doi:10.1029/2010JG001434.

\section{Introduction}

[2] The long-term effectiveness of the North American forest carbon (C) sink will depend in part on how the processes controlling the transformations and fate of soil organic $\mathrm{C}$ (SOC) will function in an elevated $\mathrm{CO}_{2}$ world [Schlesinger and Lichter, 2001; Langley et al., 2009]. Though the magnitude of organic matter inputs to the soil profile, the precursors of SOC, may increase in an elevated $\mathrm{CO}_{2}$ world [Matamala et al., 2003; Lichter et al., 2005; Huang et al., 2007; Pritchard et al., 2008], most C associated with increased litterfall is released as $\mathrm{CO}_{2}$ relatively soon after its deposition [Schlesinger and Lichter, 2001; Bernhardt et al., 2006]. However, the fate of material remaining in the soil profile for longer time periods with elevated $\mathrm{CO}_{2}$ is unclear [Billings et al., 2010]. Greater inputs could promote increased SOC formation and stabilization [Hoosbeek et al.,

\footnotetext{
${ }^{1}$ Department of Earth Science, Memorial University of Newfoundland, St. John's, Newfoundland and Labrador, Canada.

${ }^{2}$ Department of Ecology and Evolutionary Biology and Kansas Biological Survey, University of Kansas, Lawrence, Kansas, USA.

Copyright 2011 by the American Geophysical Union. 0148-0227/11/2010JG001434
}

2006], or induce a priming effect that presumably would increase turnover of extant SOC pools by soil microbial communities [Hoosbeek et al., 2006; Carney et al., 2007]. Several studies report altered activities of heterotrophic microorganisms in forest soils with elevated $\mathrm{CO}_{2}$ [Billings and Ziegler, 2005, 2008; Finzi et al., 2006; Carney et al., 2007; Langley et al., 2009]. Collectively, these studies suggest that the degree to which substrate inputs to the soil profile are retained versus mineralized may change in a high $\mathrm{CO}_{2}$ world: in other words, that the aggregated $\mathrm{C}$ use efficiency of the microbial communities within a soil profile, perhaps influenced by the chemical composition of microbial biomass itself, may change.

[3] Further complicating the complex processes regulating the cycling and fate of SOC, nitrogen (N) availability can drive the response of forest productivity to elevated $\mathrm{CO}_{2}$ [Oren et al., 2001; Finzi et al., 2007], and in turn impact SOC processes including heterotrophic respiration $\left(\mathrm{R}_{\mathrm{h}}\right)$ via changes in litterfall and root exudates [Andrews and Schlesinger, 2001; Bernhardt et al., 2006; Pregitzer et al., 2006]. Nitrogen availability also can influence microbial community structure and function directly, with associated effects on SOC cycling and loss [Waldrop et al., 
2004a, 2004b]. Enhanced N availability, for example, can reduce soil $\mathrm{R}_{\mathrm{h}}$ even when forest productivity has been enhanced by elevated $\mathrm{CO}_{2}$ [Maier and Kress, 2000; Butnor et al., 2003]. It is not clear, however, if these declines in $\mathrm{R}_{\mathrm{h}}$ with $\mathrm{N}$ fertilization are driven by changes in autotrophic or heterotrophic activities. Some incubation studies report $\mathrm{R}_{\mathrm{h}}$ declines with added $\mathrm{N}$ [Agren et al., 2001; Teklay et al., 2007; Billings and Ziegler, 2008], suggesting that altered heterotrophic activity may be an important driver of reduced soil $\mathrm{CO}_{2}$ fluxes with enhanced $\mathrm{N}$ availability observed in the field.

[4] At the longest running elevated $\mathrm{CO}_{2}$ experiment in an intact forest ecosystem (the Duke Free Air C Enrichment (FACE) site, North Carolina, USA), increases in NPP with elevated $\mathrm{CO}_{2}$ have been sustained since 1999 [Schlesinger et al., 2006]. However, relative increases in soil $\mathrm{R}_{\mathrm{h}}$ have declined since that time [Bernhardt et al., 2006], suggesting that soil microbial community function has changed over the past 10 years. Further, incubation studies indicate reduced $\mathrm{R}_{\mathrm{h}}$ in soils receiving $\mathrm{N}$ fertilizer months prior to collection [Billings and Ziegler, 2008], suggesting that changes in soil $\mathrm{N}$ cycling can regulate $\mathrm{R}_{\mathrm{h}}$ in these forest soils by altering the activity of the soil microbial community. Gram-positive bacteria, actinomycetes, and fungi access recently formed $\mathrm{SOC}$ in these elevated $\mathrm{CO}_{2}$ soils to a greater extent than in control soils, and $\mathrm{N}$ fertilization promotes the use of recently formed photosynthates by Gram-negative bacteria while reducing that of Gram-positive bacteria, particularly actinomycetes [Billings and Ziegler, 2008]. Overall these results are congruent with the idea that $\mathrm{N}$ limitation brought on by elevated $\mathrm{CO}_{2}$ may stimulate fungal and actinomycete activities. If realized, this mechanism could promote degradation of SOC pools typically exhibiting relatively slow turnover times with elevated $\mathrm{CO}_{2}$ [McCarthy and Williams, 1992; Paul and Clark, 1996; Fierer et al., 2003a].

[5] There are obvious challenges associated with experimentally augmenting $\mathrm{N}$ limitation in elevated $\mathrm{CO}_{2}$ plots to discern how soil microorganisms may function in the future. Experimentally lowering soil $\mathrm{N}$ levels in field plots is not possible without extensive manipulation that would greatly alter the soil structure, chemistry and biology we are interested in studying. Instead, we examine the influence of legacy effects of years of low-level $\mathrm{N}$ amendments on relative activities of multiple microbial groups to assess microbial responses to elevated $\mathrm{CO}_{2}$ with varying degrees of $\mathrm{N}$ limitation. Specifically, we employ the varied $\mathrm{N}$ status resulting from $\mathrm{N}$ amendments in these soils and compare $\mathrm{N}$ amended versus more severely $\mathrm{N}$ limited soils as a way of understanding which microbial groups may experience a competitive advantage for substrate access in the future, when $\mathrm{N}$ limitation with elevated $\mathrm{CO}_{2}$ is predicted to increase [Luo et al., 2004]. By observing how legacy effects of field $\mathrm{N}$ amendments can govern microbial responses to elevated $\mathrm{CO}_{2}$, we can develop hypotheses about how future, enhanced $\mathrm{N}$ limitation with elevated $\mathrm{CO}_{2}$ will influence the competitive advantages of and organic substrate flow through multiple microbial groups.

[6] As part of a larger project aimed at understanding the impact of elevated $\mathrm{CO}_{2}$ and $\mathrm{N}$ dynamics on the cycling and fate of SOC, we address two questions: Does elevated
$\mathrm{CO}_{2}$ and/or $\mathrm{N}$ limitation: (1) promote activity of actinomycetes and fungi, oligotrophic microorganisms more associated with the degradation of relatively slow-turnover SOC than their more copiotrophic counterparts [Rob et al., 1997; Schroter et al., 2003; Waldrop and Firestone, 2004]; and (2) Do these perturbations alter the fate of labile soil inputs such that the balance between losses of these inputs to $R_{h}$ changes relative to their retention in the living soil microbial biomass? In earlier works, we addressed the first question by tracing the distinct $\delta^{13} \mathrm{C}$ signature of elevated $\mathrm{CO}_{2}$ photosynthate at Duke FACE into multiple soil microbial groups [Billings and Ziegler, 2005,2008 ], but because of the lack of a similarly distinct $\delta^{13} \mathrm{C}$ label in control plots we could not draw firm conclusions about the effect of elevated $\mathrm{CO}_{2}$ in the field. By adding ${ }^{13} \mathrm{C}$ labeled substrates to these soils in laboratory incubations, however, we can design appropriately controlled experiments. Tracking the fate of individual substrates commonly encountered by soil microbial communities can be advantageous over using labeled litter, in which ${ }^{13} \mathrm{C}$ labeling can vary significantly among compound classes [Benner et al., 1987; Hayes, 2001]. The second question invokes an exploration of microbial $\mathrm{C}$ use efficiency, a parameter notoriously challenging to quantify [Holland and Coleman, 1987; del Giorgio and Cole, 1998; Thiet et al., 2006]. However, we can address associated questions by examining how microbial processing of individual substrates, proxies for recently formed organic compounds in a soil, is influenced by elevated $\mathrm{CO}_{2}$ and altered $\mathrm{N}$ status.

[7] To address these questions, we followed the fate of ${ }^{13} \mathrm{C}$-labeled substrates (glucose and vanillin) added to soils from the Duke FACE site in a series of relatively short-term incubation experiments. Glucose and vanillin represent substrates similar to root exudates (glucose) and derived from cellulose and lignin (glucose and vanillin, respectively), biomolecules commonly derived from litterfall and dead roots. We assessed activity levels of multiple microbial groups and their partitioning of added $\mathrm{C}$ into $\mathrm{R}_{\mathrm{h}}-\mathrm{CO}_{2}$ versus components of microbial cell walls, which are composed of several compounds known to serve as precursors to relatively slow-turnover soil organic matter [Guggenberger et al., 1999], and how these activities varied with elevated $\mathrm{CO}_{2}$ and soil $\mathrm{N}$ status. Interpreting data from soil incubations can be challenging because conditions are necessarily different from those in situ, but tracking the fate of ${ }^{13} \mathrm{C}$ labeled substrates of varying lability in short-term incubations permits us to assess the relative abilities of microbial groups to compete for individual substrates in a controlled environment [Waldrop and Firestone, 2004], to observe how substrate inputs are initially processed [Boschker and Middelburg, 2002; Phillips et al., 2002], and to highlight the mechanisms determining the degree to which soil inputs are respired versus incorporated into microbial biomass, where it has a chance of being transformed into relatively slow-turnover soil organic matter (SOM). Further, such experiments can guide the development of hypotheses for future studies, when direct observation of altered SOC pool sizes that change slowly over time becomes increasingly more feasible, and when ${ }^{13} \mathrm{C}$ labels provided in the field become increasingly incorporated into relatively slow- 
turnover pools and the microbial communities that access them.

\section{Materials and Methods}

\subsection{Study Site and Sample Collection}

[8] The Duke FACE experiment was established in a loblolly pine (Pinus taeda L.) forest planted in 1983 in Orange County, North Carolina, USA $\left(35^{\circ} 58^{\prime} \mathrm{N}, 79^{\circ} 05^{\prime} \mathrm{W}\right)$. Soils at the site possess relatively low fertility, and are classified as Ultic Hapludalfs (Enon series). Three of the eight, $30 \mathrm{~m}$ diameter plots established have been exposed elevated atmospheric $\mathrm{CO}_{2}\left(\sim 200 \mu \mathrm{l} \mathrm{1}^{-1}\right.$ above ambient concentrations) since August 1996; one plot has been exposed to treatment since July 1994. Further details on the site are available in several other studies [Andrews and Schlesinger, 2001; Lichter et al., 2005; Finzi et al., 2006; Schlesinger et al., 2006]. Briefly, circular treatment plots are defined and fumigated with supplemental $\mathrm{CO}_{2}$ via pipes that extend to the top of the canopy. Control plots are similarly designed, but supplied with air through these pipes with ambient atmospheric $\mathrm{CO}_{2}$ levels. Since 1998, half of each of the eight plots (two of four quadrants) has been fertilized with $\mathrm{NH}_{4} \mathrm{NO}_{3}$ each spring $\left(11.2 \mathrm{~g} \mathrm{~N} \mathrm{~m}^{-2} \mathrm{yr}^{-1}\right)$. This fertilization rate represents approximately $10 \%$ of the gross rates of $\mathrm{N}$ mineralization reported for the top $10 \mathrm{~cm}$ of the soil profile at this site [Zak et al., 2003], and about one order of magnitude greater than local atmospheric $\mathrm{N}$ deposition in both wet and dry forms $\left(1.37 \mathrm{~g} \mathrm{~N} \mathrm{~m}^{-2}\right)$ [Sparks et al., 2008].

[9] We collected two soil samples (mineral soil profile, $5 \mathrm{~cm}$ diameter, $30 \mathrm{~cm}$ deep) from all four quadrants in each plot, including fertilized and unfertilized halves, of all eight plots in late October and early November 2005. Approximately $99 \%$ of this forest's root biomass is contained within the top $30 \mathrm{~cm}$ [Matamala and Schlesinger, 2000] and root biomass is relatively high in forests such as this in October and November [McClaugherty et al., 1982; Waring and Schlesinger, 1985]. Samples were subsequently shipped in coolers to the University of Kansas for processing. Soils were sieved $(2 \mathrm{~mm})$ and all roots $>1 \mathrm{~mm}$ in diameter removed, with soil clinging to roots returned to the soil samples. The four cores collected from each fertilized and unfertilized half-plots (two from each quadrant) were pooled to generate one homogenized sample from each plot's fertilized and unfertilized sections, to generate a total of four homogenized samples from each treatment: elevated $\mathrm{CO}_{2}$ fertilized plots, elevated $\mathrm{CO}_{2}$ unfertilized plots, control fertilized plots, and control unfertilized plots. Soils were stored at $4^{\circ} \mathrm{C}$, except when being readied for incubation experiments in the laboratory, for approximately 2 weeks, until processing was completed and incubations commenced.

[10] At the time of collection, differences in inorganic $\mathrm{N}$ availability associated with $\mathrm{N}$ fertilization were not evident, nor were differences in organic $\mathrm{N}$ in bulk soil or SOM fractions separated by size fractionation or hydrolysis (S. Billings, unpublished data, 2008). Known legacies of fertilization on soil $\mathrm{N}$ status at the time of soil collection include enhanced uptake of photosynthate by Gram-negative soil microorganisms, slight but significant declines in activity of the extracellular enzyme $\mathrm{N}$-acetyl-glucosamine, and significant, large increases in urease activity [Billings and Ziegler, 2008]. Additional influences of $\mathrm{N}$ fertilization at the site on N-related soil properties include declines in abundance of some ectomycorrhizal taxa [Parrent and Vilgalys, 2007], reduced biomass-specific rates of root exudation [Phillips et al., 2009], increased arbuscular mycorrhizal infection rates, and reduced $\mathrm{C}: \mathrm{N}$ ratios of foliar litterfall (J. Li et al., unpublished data, 2009). Combined, these results indicate a legacy effect of $\mathrm{N}$ fertilization on microbially mediated SOM transformations that alters soil $\mathrm{N}$ status in complex ways, and that this effect is an important driver of belowground activity even when differences in inorganic $\mathrm{N}$ availability are undetectable.

\subsection{Soil Incubations}

[11] We weighed $30 \mathrm{~g}$ of field moist soil into $\sim 1 \mathrm{~L}$ incubation jars, establishing the 5 laboratory replicates for each soil treatment required for the 5 time points destructively sampled during the time course experiment. To one set of control replicates we added water to bring the soils to $60 \%$ water holding capacity (WHC, as determined on sieved samples). Two other sets of replicates received a ${ }^{13} \mathrm{C}$-labeled substrate as either glucose (1954\%; D-gluco$\mathrm{se}^{-13} \mathrm{C}_{6}$; Sigma Aldrich) or vanillin (1888\%o; vanillinring ${ }^{-13} \mathrm{C}_{6}$; Sigma Aldrich) in deionized water to $60 \% \mathrm{WHC}$ in order to determine treatment effects on microbial use of substrates with contrasting reactivity. Because the carboxylicand methoxy-C of the vanillin were not ${ }^{13} \mathrm{C}$-labeled, initial steps (decarboxylation and demethoxylation or demethylation) of vanillin degradation will liberate $\mathrm{C}$ possessing $\delta^{13} \mathrm{C}$ signatures that are not distinct from background levels. However, byproducts of the phenolic ring comprising vanillin, which eventually participate in ATP production and metabolite generation [Ribbons and Ohta, 1970; Crawford, 1981; Dec et al., 2001], and hence PLFA, were fully labeled with ${ }^{13} \mathrm{C}$. As a result, our approach permits us to test treatment differences in the relative accessibility and fates of both a simple ring $\mathrm{C}$ (monosaccharide) and more complex ring $\mathrm{C}$ (phenol) from the added glucose and vanillin substrates, respectively. Substrate additions were equivalent to $\sim 8 \%$ of mineralizable SOC $\left(170 \mu \mathrm{g} \mathrm{C} \mathrm{g}_{\text {soil }}^{-1}\right)$, as calculated from total $\mathrm{C}$ respired in long-term incubations presented by Billings and Ziegler [2008]. All additions were mixed well with the soil.

[12] Jars were then sealed with air-tight lids equipped with septa for gas sampling, and two, $14 \mathrm{ml}$ gas samples were immediately taken from each jar to establish starting $\mathrm{CO}_{2}$ concentration and isotopic composition in the incubation vessels. One sample was injected into a previously evacuated, air-tight vial (Teledyne Tekmar, Akron, Ohio, USA) for analysis of $\mathrm{CO}_{2}$ concentration. The other sample was injected into a previously evacuated, air-tight Exetainer (Labco, Buckinghamshire, England) for analysis of $\delta^{13} \mathrm{C}$ of $\mathrm{CO}_{2}$. For subsequent time points we destructively sampled one set of soils and immediately froze them at $-70^{\circ} \mathrm{C}$ for PLFA extraction and analyses immediately after gas sampling. All incubations were conducted at $22^{\circ} \mathrm{C}$. Incubation jars were sampled at time $0,8,18,36$ and $60 \mathrm{~h}$ for all three treatments (DI water control, glucose, and vanillin) with the exception of $60 \mathrm{~h}$ for glucose amendments; pilot studies confirmed that glucose is incorporated into SOC or respired significantly before $60 \mathrm{~h}$ in these soils (see below). These samples were frozen until data from pilot studies could be 
analyzed to determine the most appropriate time points to use to assess incorporation of labeled substrates into PLFA.

[13] We conducted a pilot study, consisting of an initial time course experiment using soils collected outside of the experimental rings at the Duke FACE site in September 2005 , to determine the time points to sample and analyze during subsequent soil incubations. This test was conducted to approximate the minimum time required to detect substrate ${ }^{13} \mathrm{C}$ in microbial PLFA to avoid significant recycling of the ${ }^{13} \mathrm{C}$ label and maximize the accuracy of the interpretation of these data. Previous studies have indicated both the significance of recycling of the added ${ }^{13} \mathrm{C}$-substrate $\mathrm{C}$ to the interpretation of active microbial groups [Ziegler et al., 2005], and a lag time between microbial uptake of ${ }^{13} \mathrm{C}$ substrates and actual mineralization [Thiet et al., 2006]. We sampled, processed, and incubated soils in the same manner described above, with a greater number of sampling time points during the pilot incubations $(0,4,12,24,48,72$, and $120 \mathrm{~h}$ ) to assess changes in ${ }^{13} \mathrm{C}$ incorporation over time. Results from this pilot study indicated that the substrates were initially respired within the first 4 and $12 \mathrm{~h}$, and initial incorporation into microbial biomass was detected in the phospholipid fatty acids (PLFA) between 12 and $24 \mathrm{~h}$ and between 24 and $48 \mathrm{~h}$ for the glucose and vanillin, respectively. We used these data to guide our choice of final time points used to investigate incorporation of glucose $(18 \mathrm{~h})$ and vanillin $(36 \mathrm{~h})$ in the full experimental incubations.

[14] $\mathrm{CO}_{2}$ concentrations were determined via gas chromatography (thermal conductivity detector, Varian CP3800, Varian Inc., Walnut Creek, California), and $\delta^{13} \mathrm{C}$ of $\mathrm{CO}_{2}$ was analyzed on a ThermoFinnigan MAT253 mass spectrometer (ThermoElectron Corporation, Bremen, Germany) in the stable isotope laboratory at the University of Kansas. Soil respiration rates were calculated from $\mathrm{CO}_{2}$ production at each sampled time point using $\mathrm{CO}_{2}$ concentration data, calculated dry weight of the soil, and the headspace of each incubation vessel. The quantity of substrate-C (glucose or vanillin-phenolic ring) respired at each time point was determined from the $\delta^{13} \mathrm{C}$ of $\mathrm{CO}_{2}$ respired in the ${ }^{13} \mathrm{C}$-labeled incubations and the DI controls, the $\delta^{13} \mathrm{C}$ of the added substrate, and the quantity of $\mathrm{CO}_{2}-\mathrm{C}$ respired using:

$$
\text { substrate }- \text { derived } \mathrm{CO}_{2}=\frac{\mu g_{\text {Cresp }}}{g} * \frac{\delta^{13} C_{\text {labelCO2 }}-\delta^{13} C_{\text {diCO2 }}}{\delta^{13} C_{\text {label }}-\delta^{13} C_{d i C O 2}}
$$

where the first term represents the quantity of $\mathrm{CO}_{2}-\mathrm{C}$ respired during the specified time interval per gram soil, $\delta^{13} \mathrm{C}_{\text {labelCO2}}$ is the $\delta^{13} \mathrm{C}$ of $\mathrm{CO}_{2}-\mathrm{C}$ respired from incubating soils receiving either glucose or vanillin additions, $\delta^{13} \mathrm{C}_{\mathrm{diCO} 2}$ is the $\delta^{13} \mathrm{C}$ of $\mathrm{CO}_{2}-\mathrm{C}$ respired from incubating soils receiving deionized water only, and $\delta^{13} \mathrm{C}_{\text {label }}$ is the $\delta^{13} \mathrm{C}$ of glucose or vanillin added.

[15] The substrate-C respired as a percent of total respiration $(\mathrm{R})$ was calculated using:

$$
\text { Substrate }-\mathrm{C} \text { respired as } \% \text { of total } \mathrm{R}=\frac{R_{\text {substrate }}}{R} * 100
$$

where $\mathrm{R}_{\text {substrate }}$ refers to the quantity of $\mathrm{CO}_{2}-\mathrm{C}$ derived from glucose or vanillin phenolic- $\mathrm{C}$ as defined in equation (1) and $\mathrm{R}$ is the total $\mathrm{CO}_{2}$ evolved at the final time point for the soil incubation.
[16] To assess whether our substrate additions stimulated the respiration of extant SOC we compared respiration of SOC across all three substrate treatments (deionized water control, glucose, and vanillin). The respiration of extant SOC in the glucose and vanillin amended soils was calculated as the difference between the total $\mathrm{CO}_{2}-\mathrm{C}$ respired and substrate- $\mathrm{C}$ respired in these incubations, while the total $\mathrm{CO}_{2}-\mathrm{C}$ respired in the deionized water control incubations was assumed to be respiration of extant SOC.

\subsection{Phospholipid Fatty Acid Analyses}

[17] Frozen soil samples collected as part of the incubation experiments were transported to the University of Arkansas for phospholipid fatty acid (PLFA) analyses. Samples were freeze-dried and extracted within 2 weeks of collection using a modified Bligh-Dyer method [Pinkart et al., 1998; White and Ringelberg, 1998] and subsequently fractionated into neutral lipids, glycolipids, and phospholipids using solid phase extraction [Dobbs and Findlay, 1993; White and Ringelberg, 1998]. Phospholipids were saponified and PLFAs transmethylated into their corresponding fatty acid methyl esters (FAMEs) according to Findlay [2007]. The resulting FAMEs were purified using reversephase solid phase extraction according to Findlay and Dobbs [1993]. FAMEs were quantified using a gas chromatograph with a flame ionization detector (GC-FID; Agilent 6890). Samples were also analyzed to identify each FAME using the same GC interfaced with a mass selective detector (Agilent 5973 inert). Identification was based on retention time and mass spectra of known standards in addition to direct comparison of mass spectra to a NIST database. PLFA sample recovery was determined from phospholipid recovery standards (phosphatidylcholine deheptadecanoyl, and phosphatidylcholine nonadecanoyl; Avanti Lipids, Alabaster, AL, USA).

[18] Phospholipid fatty acids provide a means of separating microbial communities into biogeochemically relevant components; here they were employed to track relative differences in the activities of these broadly defined groups. Functional group separation, rather then phylogenetic separation, was the ultimate goal in this study. As such, we assessed the quantities and activity levels of Gram-positive bacteria, Gram-negative bacteria, actinomycetes (a specific group of Gram positive bacteria important for SOC transformations), and fungi. Terminally branched PLFA and monounsaturated PLFA were used to investigate substrate incorporation into Gram positive and Gram negative organisms, respectively [Ringelberg et al., 1989; Zelles et al., 1992; White et al., 1996]. Because previous work demonstrated the importance of discerning relative activity levels of actinomycetes and fungi [Billings and Ziegler, 2005, 2008], we used $10 \mathrm{Me} 18: 0$ and $18: 1 \omega 9+18: 2 \omega 6$ to investigate the role of these two groups, respectively [Federle, 1986;

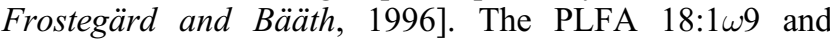
$18: 2 \omega 6$ were assessed separately because $18: 1 \omega 9$, though common in fungi, may also be found in bacteria [Frostegärd et al., 1993a; Frostegärd and Bääth, 1996; Olsson, 1999]. Here $18: 1 \omega 9$ is only used to corroborate the results for $18: 2 \omega 6$, which is a more specific biomarker for fungi in soil. Further, we used the sum of 16:0 and 18:0 as a means to track substrate $\mathrm{C}$ into the general microbial community, and refer to this sum as the "general" microbial grouping. 
[19] Stable C isotopic composition of individual FAMEs was determined using an Agilent 6890 GC coupled to a stable isotope ratio mass spectrometer (Thermo Finnigan Delta $^{+}$) via a combustion interface (Thermo Finnigan GC/ CIII; GC-C-IRMS). The same GC column, injector, flow and oven parameters used for the quantification and identification of PLFA via GC-FID and GCMS were employed for the GC-C-IRMS analyses. A standard mixture of four phospholipids, each with fatty acid moieties that were predetermined for $\delta^{13} \mathrm{C}$, was used to correct each fatty acid for the addition of the methyl $\mathrm{C}$ by mass balance [Silfer et al., 1991; Abrajano et al., 1994]. $\delta^{13} \mathrm{C}$ values were measured relative to high purity, reference gas standards expressed relative to international standard PDB (Pee Dee Belemnite). Accuracy, determined from a working standard of 8 saturated fatty acids, ranged between 0.1 and $0.4 \%$ and precision for FAMEs analyzed were determined from triplicate injections of samples, and ranged between 0.2 and $0.6 \%$.

[20] Substrate-C incorporation into individual PLFA was calculated as:

$$
\begin{aligned}
\text { Substrate derived PLFA C }= & \frac{\mu g P L F A-C}{g} \\
& * \frac{\delta^{13} C_{\text {label-PLFA }}-\delta^{13} C_{d i-P L F A}}{\delta^{13} C_{\text {label }}-\delta^{13} C_{d i-P L F A}}
\end{aligned}
$$

where the first term represents the quantity of an individual PLFA in $\mu \mathrm{g} \mathrm{C}$ at the final time interval per gram soil, $\delta^{13} \mathrm{C}_{\text {label-PLFA }}$ is the $\delta^{13} \mathrm{C}$ of the individual PLFA at the final time interval in soil receiving either glucose or vanillin additions, $\delta^{13} \mathrm{C}_{\mathrm{di} \text {-PLFA }}$ is the $\delta^{13} \mathrm{C}$ of an individual PLFA at that same final time interval but in soil receiving deionized water only, and $\delta^{13} \mathrm{C}_{\text {label }}$ is the $\delta^{13} \mathrm{C}$ of glucose or vanillin added. Slight negative values for this measure could be encountered when no significant incorporation of substrate occurs due to the variation in the $\delta^{13} \mathrm{C}$ of PLFA from the treatment and DI controls. The substrate-derived PLFA-C was calculated for all individual PLFA that could be resolved isotopically as well as groups of PLFA representing Gram negative and Gram positive organisms, and general and total PLFA. The calculation for groups was accomplished by summing the substrate-derived PLFA-C for each individual PLFA representing that group.

[21] The calculated substrate-derived PLFA-C was used to estimate relative substrate use among the broadly defined microbial groups by calculating the substrate-derived $\mathrm{C}$ in an individual PLFA as a percent of total PLFA-C derived from the substrate as determine from the summation of substrate-derived $\mathrm{C}$ in all PLFA resolved:

$$
\begin{aligned}
& \text { Substrate derived } \mathrm{C} \text { as } \% \text { total PLFA } \\
& =\frac{\text { substrate derived PLFA } C_{\text {individual }}}{\sum \text { substrate derived PLFA } C_{\text {individual }}} * 100
\end{aligned}
$$

where substrate derived PLFA $\mathrm{C}_{\text {individual }}$ represents the quantity of glucose or vanillin phenolic- $\mathrm{C}$ incorporated into an individual PLFA and the summation is that for all PLFA resolved isotopically from the soil sample. This measure of the relative substrate- $\mathrm{C}$ incorporation was used to determine potential shifts in the composition of the active microbial community with elevated $\mathrm{CO}_{2}$ or $\mathrm{N}$ fertilization.
[22] To assess potential differences in the efficiency with which soil microbial communities incorporated substrate-C into microbial biomass, we calculated a PLFA-based proxy for substrate use efficiency (PLFA-based SUE):

$$
\begin{aligned}
& \text { PLFA - based SUE } \\
& \qquad=\frac{\sum \text { substrate derived PLFA } C_{\text {individual }}}{\sum \text { substrate derived PLFA } C_{\text {individual }}+\text { substrate derived } \mathrm{CO}_{2}}
\end{aligned}
$$

where the summation is that for all PLFA resolved isotopically in the soil and substrate-derived $\mathrm{CO}_{2}$ (equation (1)) for either glucose- or vanillin phenolic-C. PLFA-based SUE is not an absolute measure of substrate use efficiency, because we consider only one class of biomolecule (PLFA), and potential recycling of the added substrate precludes us from accurately obtaining total microbial substrate-C use. However, because PLFA provides a robust measure of community composition and relative estimates of biomass [White and Findlay, 1988; Tunlid and White, 1992; Zelles et al., 1992; Frostegärd et al., 1993b; Frostegärd and Bääth, 1996], PLFA-based SUE is a useful means of assessing responses of relative SUE to experimentally imposed variation in $\mathrm{CO}_{2}$ and $\mathrm{N}$ dynamics.

\subsection{Statistical Analyses}

[23] Rates of soil respiration were tested to determine if the substrate additions themselves, in addition to the elevated $\mathrm{CO}_{2}$ and $\mathrm{N}$ amendment, affected soil community respiration, using a generalized linear model (GLM [Lindsey, 1997]; JMP 7.1; SAS; Cary, North Carolina). A subsequent pair of GLMs were conducted to test the two separate substrate amendments (glucose and vanillin) relative to the respective DI-control, to determine which substrates were responsible for the overall model substrate effect on soil respiration. We tested for the effect of substrate addition on the respiration of extant SOC, the effects of $\mathrm{CO}_{2}$ and $\mathrm{N}$ fertilization, and the interaction of elevated $\mathrm{CO}_{2}$ and $\mathrm{N}$ addition on the relative substrate incorporation into individual and groups of PLFA using GLM as well. It is important to note that statistical tests of $\mathrm{N}$ amendments on microbial function assess the combined influence of all legacy effects of fertilization on soil $\mathrm{N}$ status described above, not the effect of variation in inorganic $\mathrm{N}$ availability, which did not vary with treatment at the time of soil collection.

[24] For each of the tests described, chi-square $\left(\chi^{2}\right)$ statistics from analysis of deviance within the framework of the GLM were used to assess significance of treatment effects and, where appropriate, their interactions. We checked assumptions of homogeneous and normal errors for each GLM [Lindsey, 1997] by plotting residuals versus fits, and by plotting residuals as probability plots. In cases where assumptions were violated, a GLM entailing the same structural model but with a different error structure was used. The exponential error distribution produced acceptable residuals in those cases where normal error assumptions were violated. The exponential distribution is a special case of the gamma distribution, and like the gamma distribution its effect is to reduce the weight given to observations exhibiting greater error [Lindsey, 1997]. In the GLMs using 

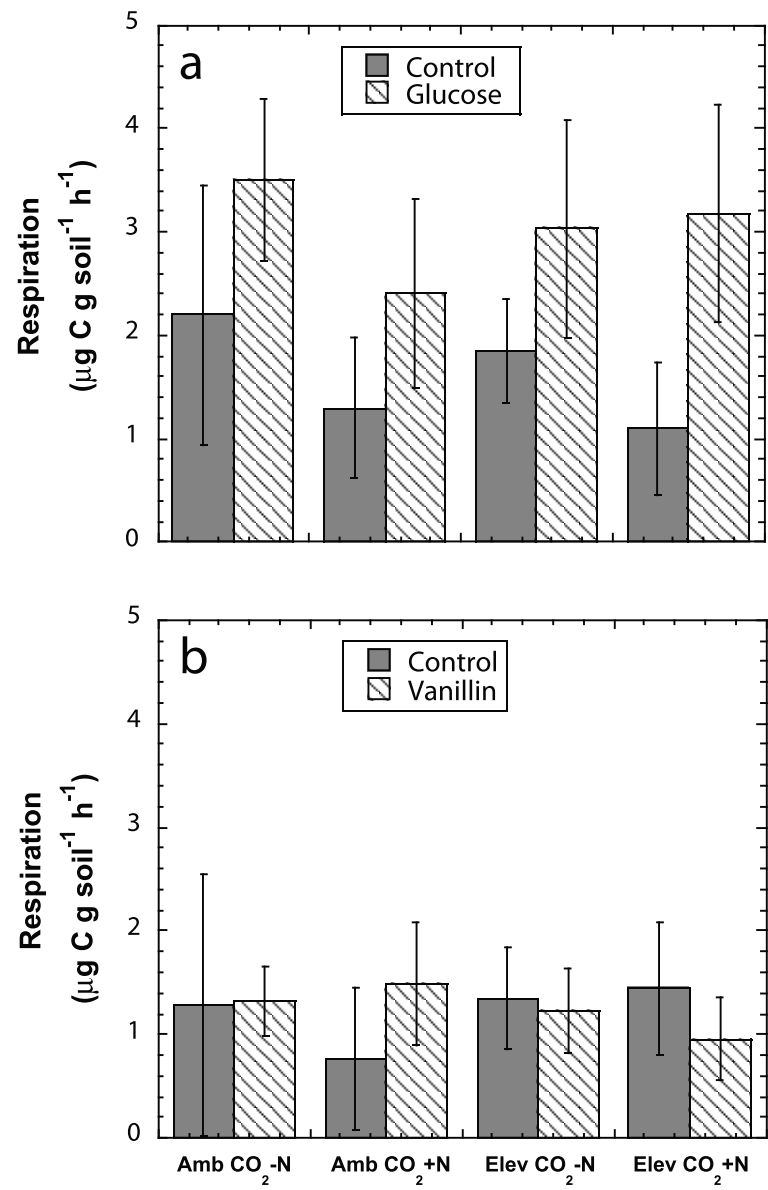

Figure 1. Rates of respiration $\left(\mu \mathrm{g} \mathrm{C} \mathrm{g} \mathrm{soil}{ }^{-1}\right)$ obtained for (a) $18 \mathrm{~h}$ soil incubations with (glucose, striped bars) and without (control, solid bars) glucose additions and (b) $36 \mathrm{~h}$ soil incubations with (vanillin, striped bars) and without (control, solid bars) vanillin additions. Values are provided as means $(n=4) \pm$ one standard deviation. Substrate level (S), as deionized water (DI) control, glucose, and vanillin, had a significant effect $\left(\chi_{2,50}^{2}=38.6, \mathrm{p}<0.0001\right)$. Glucose amended soils exhibited a significantly higher respiration rate relative to the DI controls $\left(\chi_{1,22}^{2}=8.16, p=0.0190\right)$ whereas vanillin amended soils were not significantly different from the respective DI control soils $\left(\chi_{1,22}^{2}=0.003, \mathrm{p}=0.4839\right)$.

the exponential error distribution (12 out of 44 total), the deviance residual by predicted plot was assessed to determine if the assumptions of the model were met before $\chi^{2}$ and $p$ values were calculated and used [Hoffmann, 2004]. All GLMs were calculated using JMP 7.1 (SAS; Cary, North Carolina). All analyses employed an alpha level of 0.05 .

\section{Results}

\subsection{Soil Respiration and the Influence of Added Substrates}

[25] Substrate treatment (S) had a significant effect on rates of soil respiration; no other factor significantly affected soil respiration in these experiments. Specifically, glucose amended soils exhibited significantly higher respiration rates relative to the DI controls for the same incubation period (Figure 1a). This effect was not observed in vanillin amended soils, for which respiration rates were not significantly different from DI control soils (Figure 1b).

[26] We observed a significant $\mathrm{S}\left(\chi_{1,16}^{2}=55.27, \mathrm{p}<\right.$ $0.0001)$ and $\mathrm{N}\left(\chi_{1,16}^{2}=4.25, \mathrm{p}=0.0392\right)$ effect on substrate$\mathrm{C}$ respired as a percent of total respiration in the substrate amended soils. Respired glucose-C represented between 57 and $63 \%$ of total respiration in the glucose amended soils while vanillin phenolic-C respired only represented between 11 and $15 \%$ of the total respired $\mathrm{CO}_{2}$ in the vanillin amended soils. Further, substrate-C respired during the incubations, regardless of substrate type, was significantly lower in the fertilized soils relative to unfertilized soils $\left(\chi_{2,36}^{2}=4.25, \mathrm{p}=0.0394\right)$, consistent with the lower concentrations of PLFA detected in the fertilized soils.

[27] We observed no significant effect of $\mathrm{S}, \mathrm{CO}_{2}$, or $\mathrm{N}$ on estimates of respiration derived from the extant SOC (total R minus substrate- $\mathrm{C}$ respired). Rates of extant $\mathrm{SOC}$ respiration ranged from 1.0 to $1.5 \mu \mathrm{g} \mathrm{CO}_{2}-\mathrm{C} \mathrm{g} \mathrm{soil}^{-1} \mathrm{~h}^{-1}$ in the glucose incubations, and from 0.7 to $1.4 \mu \mathrm{g} \mathrm{CO}_{2}-\mathrm{C} \mathrm{g}$ soil $^{-1} \mathrm{~h}^{-1}$ in the vanillin incubations, and were both comparable to rates observed in the deionized water control soils (1.1 to $2.2 \mu \mathrm{g}$ $\mathrm{CO}_{2}-\mathrm{C}$ g soil ${ }^{-1} \mathrm{~h}^{-1}$ ).

\subsection{Soil Phospholipid Fatty Acids and the Incorporation of Substrates}

[28] Total phospholipid fatty acid concentration in all soils ranged from 58 to 89 nmol PLFA g soil ${ }^{-1}$ and exhibited a significant $\left(\chi_{1,12}^{2}=5.2 ; \mathrm{p}=0.0224\right)$, negative $\mathrm{N}$ effect (mean values of 60 and 85 nmol PLFA g soil ${ }^{-1}$ for the fertilized and unfertilized soils, respectively), consistent with other studies attributing such responses to competitive interactions [Parrent et al., 2006; Parrent and Vilgalys, 2007] and relative reductions in soil C availability [Waldrop et al., 2004a, 2004b; Hogberg et al., 2007]. There were 25 individual PLFA detected and quantified in all samples. Functional groups investigated include eight Gram-positive bacterial PLFA (ia15:0, ia16:0, ia17:0, 10Me17:0, 10Me18:0), eight Gram-negative bacterial PLFA (16:1 $\omega 7$, three separate 16:1 PLFA where the monounsaturation point was not clearly identified, cy17:0, 18:1 $\omega 7,18: 1 \omega 5$, cy19:0), one fungal

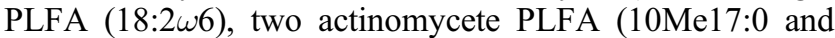
10Me18:0), and one PLFA associated with fungi and, to a

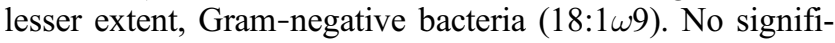
cant differences in PLFA composition (weight \% Gramnegative bacteria, Gram-positive bacteria, fungi, ratio of bacteria/fungi) were observed with any treatment in these soils, except for weight \% of 10Me18:0 which exhibited a significant, positive $\mathrm{N}$ fertilization effect $\left(\chi_{1,12}^{2}=17.5 ; \mathrm{p}<\right.$ $0.0001)$.

[29] We resolved the $\mathrm{C}$ isotopic composition of six of the eight Gram-positive and six of the eight bacterial PLFA detected, the fungal PLFA, one actinomycete PLFA, $18: 1 \omega 9$, and the two PLFA assigned to the general group (16:0 and 18:0). Glucose and vanillin amendments were both incorporated into these PLFA. We observed significant $\mathrm{S}, \mathrm{N}$ and $\mathrm{S}^{*} \mathrm{~N}$ effects on substrate-C incorporation into the total soil PLFA pool. Across the total PLFA pool, incorporation of glucose- $\mathrm{C}$ was greater than vanillin phenolic-C (Figure 2). Incorporation of glucose- $\mathrm{C}$ exhibited a significant increase in the fertilized soils. This effect was not 


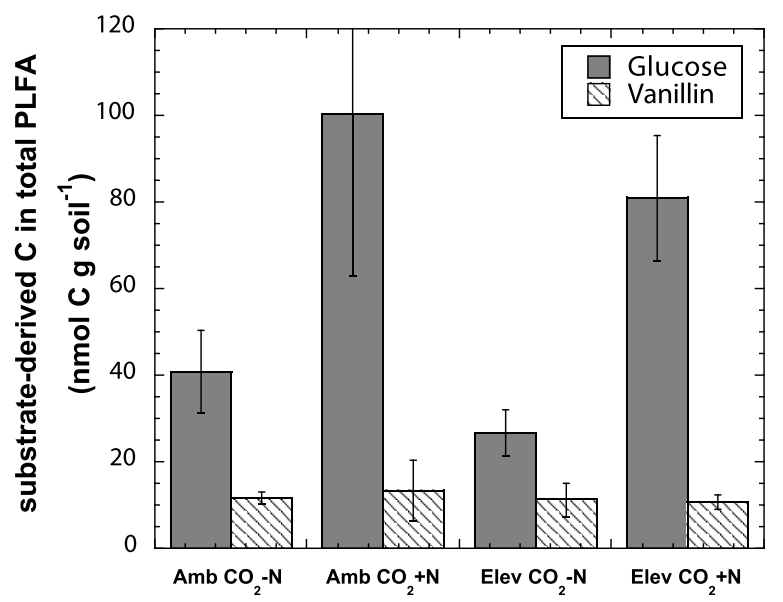

Figure 2. Incorporation of glucose carbon (C) and vanillin phenolic-C into the total soil phospholipid fatty acid (PLFA) pool in ambient $\mathrm{CO}_{2}$ soils without added nitrogen (Amb $\left.\mathrm{CO}_{2}-\mathrm{N}\right)$ and with added nitrogen $\left(\mathrm{Amb} \mathrm{CO}_{2}+\mathrm{N}\right)$, elevated $\mathrm{CO}_{2}$ soils without added nitrogen (Elev $\left.\mathrm{CO}_{2}-\mathrm{N}\right)$ and with added nitrogen $\left(\right.$ Elev $\left.\mathrm{CO}_{2}+\mathrm{N}\right)$. Values are means $(\mathrm{n}=4)$ \pm one standard deviation. Significant substrate $\left(\mathrm{S} ; \chi_{1,23}^{2}=\right.$ $36.9 ; \mathrm{p}<0.0001), \mathrm{N}\left(\chi_{1,23}^{2}=6.6 ; \mathrm{p}=0.0343\right)$ and $\mathrm{S} * \mathrm{~N}$ $\left(\chi_{1,23}^{2}=6.5 ; \mathrm{p}=0.0362\right)$ effects on substrate-C incorporation into the total soil PLFA pool were observed with incorporation of glucose-C into the total PLFA pool having exhibited a significant $\left(\chi_{1,11}^{2}=3.908 ; p=0.0315\right)$ increase within the fertilized soils.

significant for vanillin phenolic-C incorporation into the total PLFA pool.

[30] Incorporation of substrate-C into PLFA of four microbial groups (Gram-negative and Gram-positive bacteria, fungi, and actinomycetes), relative to incorporation of substrate-C total PLFA exhibited a significant $\mathrm{S}$ effect (Table 1), with a greater proportion of vanillin phenolic-C incorporated into Gram-negative bacterial PLFA relative to glucose-C incorporation. The opposite effect occurred in the other groupings (Gram-positive bacteria, fungi, actinomycetes; Figures 3 and 4). Similarly, a significant S effect was observed for the relative incorporation of substrate-C into the "general" PLFA $\left(\chi_{1,22}^{2}=17.13 ; \mathrm{p}<0.0001\right)$ such that greater incorporation of glucose occurred relative to vanillin phenolic-C. Elevated $\mathrm{CO}_{2}$ imposed a positive effect of relative substrate-C incorporation into both actinomycete and fungal PLFA, which varied with substrate (Table 1 and Figure 4). We observed a negative effect of elevated $\mathrm{CO}_{2}$ $\left(\chi_{1,22}^{2}=6.43 ; \mathrm{p}=0.0112\right)$ on relative substrate- $\mathrm{C}$ incorporation into general PLFA biomarkers, an effect that was not substrate specific.

[31] A significant $\mathrm{S} * \mathrm{CO}_{2}$ effect on relative substrate incorporation into both actinomycete and fungal PLFA 18:2 $\omega 6$, and a significant $\mathrm{S} * \mathrm{~N}$ effect on relative substrate incorporation into actinomycete PLFA (Table 1) prompted us to test the effect of $\mathrm{CO}_{2}$ and $\mathrm{N}$ on the relative incorporation of the two substrates separately. We observed a significant, positive effect of elevated $\mathrm{CO}_{2}$ on relative glucose$\mathrm{C}$ incorporation into the fungal PLFA 18:2 $\omega 6$ (Table 2 and Figure 4b). We also observed a significant, positive effect of elevated $\mathrm{CO}_{2}$ and a negative effect of $\mathrm{N}$ amendments on relative vanillin phenolic-C incorporation into actinomycete PLFA (Table 2 and Figure 4c).

\subsection{Phospholipid Fatty Acid-Based Substrate Use Efficiency}

[32] A significant $\mathrm{CO}_{2} * \mathrm{~N}$ effect on PLFA-based SUE was observed for vanillin but not for glucose $\left(\chi_{1,8}^{2}=1.13, \mathrm{p}=\right.$ 0.2887), such that PLFA-based SUE for vanillin phenolic-C increased by $46 \%$ with $\mathrm{N}$ fertilization only in the elevated $\mathrm{CO}_{2}$ soils (Figure 5a). The increase in PLFA-based SUE with $\mathrm{N}$ treatment was congruent with increased overall substrate- $\mathrm{C}$ incorporation into PLFA with $\mathrm{N}$ fertilization in these soils. Further, the significant $\mathrm{S} * \mathrm{~N}$ interaction effect on PLFA-based SUE was due to the significant increased glucose PLFA-based SUE with the field additions of $\mathrm{N}$ which was not observed for vanillin PLFA-based SUE $\left(\chi_{1,8}^{2}=0.64, \mathrm{p}=0.4240 ;\right.$ Figure 5).

\section{Discussion}

[33] Because of the challenges of directly observing changes in the size of SOC pools in situ, the lack of in situ ${ }^{13} \mathrm{C}$ labeling in control plots at Duke FACE, and the difficult nature of imposing $\mathrm{N}$ limitation in the field, we employed ${ }^{13} \mathrm{C}$ tracers in soil ex situ to assess how the activity levels of microbial groups associated with the degradation of SOC pools respond to elevated $\mathrm{CO}_{2}$ and varied soil $\mathrm{N}$ status. By invoking isotopic labeling in a laboratory setting, we demonstrate that both elevated $\mathrm{CO}_{2}$ and the legacies of $\mathrm{N}$ amendments can influence the relative activity of soil microbial groups. These effects, in turn, influence incorporation of some organic $\mathrm{C}$-substrates into microbial PLFA and, presumably, microbial biomass more generally. Thus altering the opportunity for the formation of relatively stabilized SOM through biomass generation versus respiratory loss. We have previously employed the distinct ${ }^{13} \mathrm{C}$ signa-
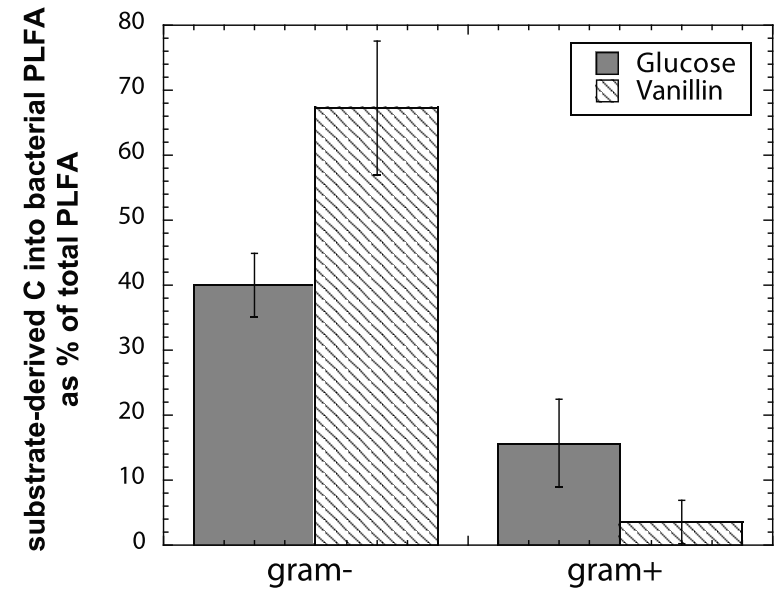

Figure 3. The proportion of glucose-derived (solid bars) and vanillin phenolic derived $C$ (striped bars) in Gram negative bacteria (gram - ) and Gram positive bacteria (gram + ) as a percent of total substrate-C incorporated in the total of all PLFA exhibiting a significant substrate $(\mathrm{S})$ effect $\left(\chi_{2,50}^{2}=\right.$ $8.2 ; \mathrm{p}=0.03835$ and $\chi_{2,50}^{2}=55.5 ; \mathrm{p}<0.0001$, respectively). There was no significant effect of elevated $\mathrm{CO}_{2}$ or $\mathrm{N}$ addition. Values are means $(n=16)$ of all four treatments \pm one standard deviation. 

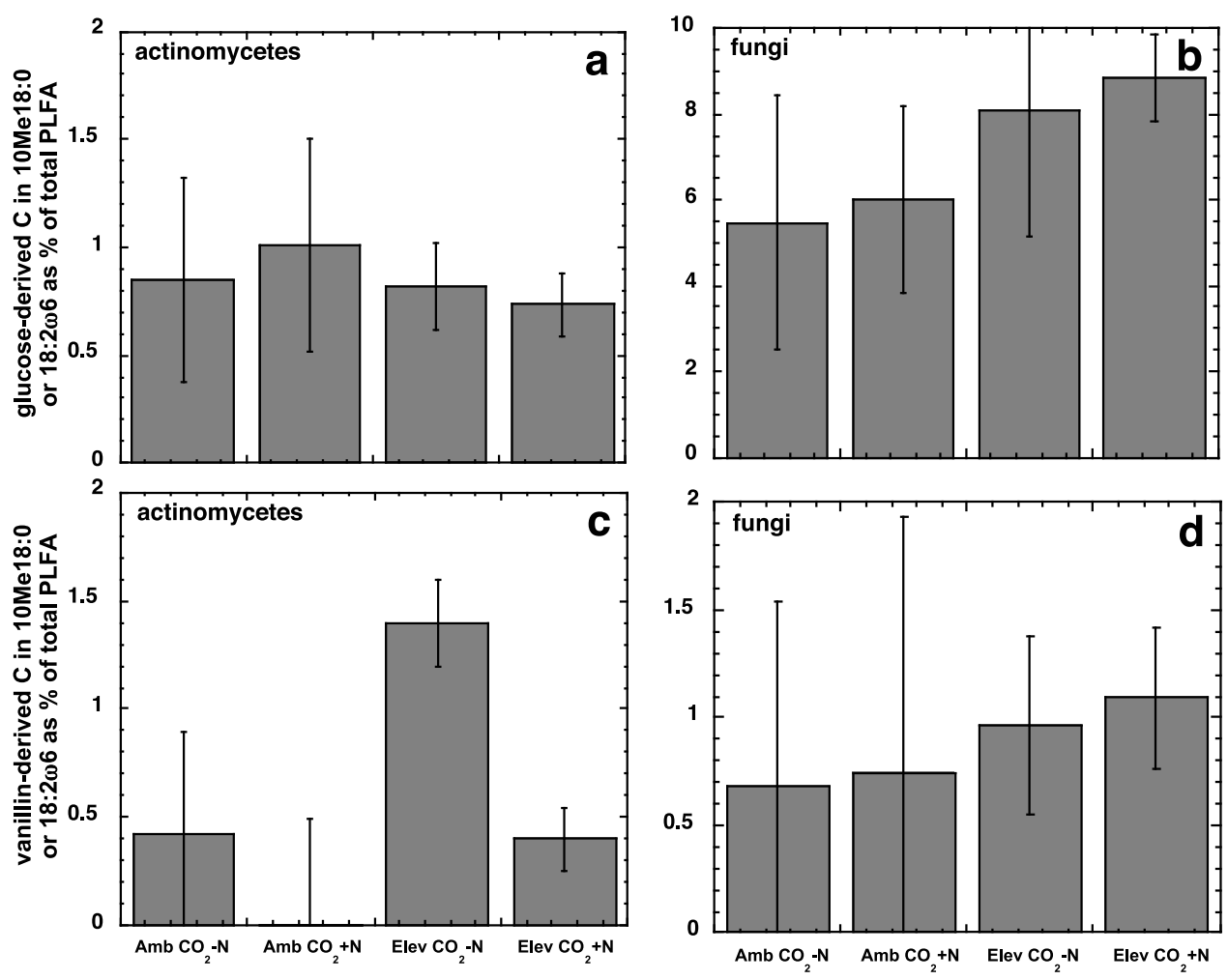

Figure 4. The proportion of (top) glucose-derived and (bottom) vanillin phenolic derived $\mathrm{C}$ in (a and c) actinomycete PLFA 10Me18:0 and ( $\mathrm{b}$ and d) fungal PLFA 18:2w6 as a percent of total substrate-C incorporated in the total of all PLFA extract from soils without added nitrogen $\left(\mathrm{Amb} \mathrm{CO}_{2}-\mathrm{N}\right)$, with added nitrogen $\left(\mathrm{Amb} \mathrm{CO} \mathrm{CO}_{2}+\mathrm{N}\right)$, elevated $\mathrm{CO}_{2}$ soils without added nitrogen $\left(\mathrm{Elev} \mathrm{CO}_{2}-\mathrm{N}\right)$ and with added nitrogen (Elev $\left.\mathrm{CO}_{2}-\mathrm{N}\right)$. Values are means $(\mathrm{n}=4) \pm$ one standard deviation. Glucose-C incorporation into the fungal 18:2 $\omega 6$ PLFA as percent of total PLFA exhibited a significant $\mathrm{CO}_{2}$ effect $\left(\chi_{1,22}^{2}=10.5 ; \mathrm{p}=\right.$ $0.0110)$. Vanillin phenolic-C incorporation into the actinomycete PLFA 10Me18:0 exhibited both a significant $\mathrm{CO}_{2}\left(\chi_{1,22}^{2}=18.0 ; \mathrm{p}=0.0014\right)$ and $\mathrm{N}\left(\chi_{1,22}^{2}=17.3 ; \mathrm{p}=0.0017\right)$ effect.

ture of recent photosynthate in elevated $\mathrm{CO}_{2}$ plots at this site to determine how elevated $\mathrm{CO}_{2}$ and varied $\mathrm{N}$ status affect microbial use of SOC [Billings and Ziegler, 2005, 2008]. The current study represents a more controlled investigation to test the hypotheses raised in those previous studies that relative actinomycete and fungal activity is greater in elevated $\mathrm{CO}_{2}$ soil, and actinomycete activity is reduced when $\mathrm{N}$ limitations are partially mitigated. In the current study, we observed greater relative use of added substrates by actinomycetes and fungi with elevated $\mathrm{CO}_{2}$, and reduced sub- strate incorporation into actinomycetes and enhanced PLFA-based SUE for vanillin phenolic-C with $\mathrm{N}$ amendments. These findings, in conjunction with the related field studies [Billings and Ziegler, 2005, 2008], suggest that the influence of elevated $\mathrm{CO}_{2}$ on the fate of enhanced $\mathrm{C}$ inputs to the soil profile with elevated $\mathrm{CO}_{2}$ at this site [Schlesinger et al., 2006] is governed by the degree of $\mathrm{N}$ limitation, which is predicted to increase in the future [Luo et al., 2004; Finzi et al., 2006].

Table 1. Chi-Square and $p$ Values From the Generalized Linear Models: Substrate-C Incorporated Into Specific PLFA (or Group of PLFA) as a Percent of the Substrate-C Incorporated Into Total Soil PLFA $=$ Substrate $(\mathrm{S})+\mathrm{CO}_{2}$ Level $\left(\mathrm{CO}_{2}\right)+\mathrm{Nitrogen}$ Level $(\mathrm{N})+$ $\mathrm{S} * \mathrm{CO}_{2}+\mathrm{S} * \mathrm{~N}+\mathrm{S} * \mathrm{CO}_{2} * \mathrm{~N}$, Where S Refers to Glucose or Vanillin Substrate Addition ${ }^{\mathrm{a}}$

\begin{tabular}{|c|c|c|c|c|c|c|c|c|c|c|c|c|c|c|}
\hline & \multicolumn{2}{|r|}{$S$} & \multicolumn{2}{|c|}{$\mathrm{CO}_{2}$} & \multicolumn{2}{|c|}{$\mathrm{N}$} & \multicolumn{2}{|c|}{$\mathrm{S} * \mathrm{CO}_{2}$} & \multicolumn{2}{|c|}{$\mathrm{S} * \mathrm{~N}$} & \multicolumn{2}{|c|}{$\mathrm{CO}_{2} * \mathrm{~N}$} & \multicolumn{2}{|c|}{$\mathrm{S} * \mathrm{CO}_{2} * \mathrm{~N}$} \\
\hline & $\chi^{2}$ & $\mathrm{P}$ & $\chi^{2}$ & $\mathrm{P}$ & $\chi^{2}$ & $\mathrm{p}$ & $\chi^{2}$ & $\mathrm{P}$ & $\chi^{2}$ & $\mathrm{p}$ & $\chi^{2}$ & $\mathrm{p}$ & $\chi^{2}$ & $\mathrm{p}$ \\
\hline gram- & 8.2 & $0.0384 *$ & 0.03 & 0.4480 & 0.01 & 0.4664 & 0.1 & 0.4220 & 0.01 & 0.4792 & 0.03 & 0.4591 & 0.04 & 0.4444 \\
\hline gram + & 55.5 & $<0.0001^{*}$ & 1.3 & 0.2105 & 2.1 & 0.1555 & 0.1 & 0.3960 & 0.7 & 0.2833 & 0.9 & 0.2462 & 0.02 & 0.4568 \\
\hline actino. & 10.0 & $0.0127^{*}$ & 11.0 & $0.0095^{*}$ & 14.9 & $0.0032 *$ & 19.0 & $0.0010^{*}$ & 16.0 & $0.0024 *$ & 1.5 & 0.1961 & 0.00 & 0.4850 \\
\hline $18: 1 \omega 9$ & 8.2 & $<0.0041^{*}$ & 0.3 & 0.5888 & 0.2 & 0.6333 & 0.1 & 0.7596 & 0.1 & 0.7365 & 0.6 & 0.4445 & 0.01 & 0.9191 \\
\hline $18: 2 \omega 6$ & 98.5 & $<0.0001^{*}$ & 12.9 & $0.0057^{*}$ & 1.0 & 0.2458 & 8.4 & $0.0202 *$ & 0.5 & 0.3056 & 0.04 & 0.4453 & 0.01 & 0.4670 \\
\hline
\end{tabular}

${ }^{\mathrm{a}}$ GLM, generalized linear models [Lindsey, 1997]; JMP 7.1; SAS; Cary, North Carolina. Results are provided for the PLFA indicative of Gram negative bacteria (gram-), Gram positive bacteria (gram+), actinomycetes (actino.), and fungi as 18:1 $\omega 9$ and 18:2 $\omega 6$ considered separately. ${ }^{*}$ signifies p values $<0.05$. 
Table 2. Chi-Square and $\mathrm{p}$ Values From the Generalized Linear Models: Glucose-Carbon (C) Incorporated Into Specific PLFA as Percent of Total PLFA $=\mathrm{CO}_{2}$ Level $\left(\mathrm{CO}_{2}\right)+$ Nitrogen Level $(\mathrm{N})+\mathrm{CO}_{2}{ }^{*} \mathrm{~N}$, and Vanillin-Phenolic C Incorporated Into Specific PLFA as Percent of Total PLFA $=\mathrm{CO}_{2}+\mathrm{N}+\mathrm{CO}_{2} * \mathrm{~N}^{\mathrm{a}}$

\begin{tabular}{|c|c|c|c|c|c|c|}
\hline & \multicolumn{2}{|c|}{$\mathrm{CO}_{2}$} & \multicolumn{2}{|c|}{$\mathrm{N}$} & \multicolumn{2}{|c|}{$\mathrm{CO}_{2} * \mathrm{~N}$} \\
\hline & $\chi^{2}$ & $\mathrm{p}$ & $\chi^{2}$ & $\mathrm{p}$ & $\chi^{2}$ & $\mathrm{p}$ \\
\hline \multicolumn{7}{|c|}{ Glucose-C Incorporated Into PLFA (Percent of Total PLFA) } \\
\hline action. & 1.67 & 0.1804 & 0.07 & 0.4270 & 1.21 & 0.2180 \\
\hline fungi & 10.5 & $0.0110^{*}$ & 0.78 & 0.2668 & 0.03 & 0.4542 \\
\hline \multicolumn{7}{|c|}{ Vanillin-Phenolic C Incorporated Into PLFA (Percent of Total PLFA) } \\
\hline actino. & 18.0 & $0.0014 *$ & 17.3 & $0.0017 *$ & 0.57 & 0.2961 \\
\hline fungi & 1.79 & 0.1722 & 0.20 & 0.3767 & 0.02 & 0.4621 \\
\hline
\end{tabular}

${ }^{\mathrm{a}}$ GLM, generalized linear models [Lindsey, 1997]; JMP 7.1; SAS; Cary, North Carolina. Results are provided for the PLFA specific to actinomycetes (actino.) and fungi as 18:2 $\omega 6$ because they were the groups exhibiting a significant interaction in the full generalized linear model (see bottom of Table 1). * signifies $\mathrm{p}$ values $<0.05$.

\subsection{Effects of Elevated $\mathrm{CO}_{2}$ and Soil N Status on Substrate-C Flow Through the Soil Microbial Community}

[34] Our results suggest a greater proportion of glucose and vanillin phenolic- $\mathrm{C}$ incorporation into actinomycetes and fungi with elevated $\mathrm{CO}_{2}$. It is likely that our isolation of PLFA prevents us from detecting variations in labeled substrate storage in other biomass components [Rinnan and Bääth, 2009], but results reported here are congruent with those from a temperate deciduous forest site where uptake of cellobiose by soil fungi was enhanced with elevated $\mathrm{CO}_{2}$ [Phillips et al., 2002], as well as incorporation of ${ }^{13} \mathrm{C}-$ labeled photosynthates in the field at this site [Billings and Ziegler, 2005, 2008]. It is unlikely that microbial communities across multiple forests, using varied substrates, would exhibit consistent trends in substrate flows through PLFA with elevated $\mathrm{CO}_{2}$ that were not reflective of more general trends in biomass. If we accept the assumption that substrate flow through PLFA is indicative of substrate flows through microbial biomass, this suggests the observed enhanced incorporation of added substrates into actinomycete and fungal PLFA with elevated $\mathrm{CO}_{2}$ is likely indicative of substrate incorporation into whole microbial biomass, as suggested by numerous PLFA studies [Tunlid et al., 1987; Pelz et al., 1997; Abraham and Hesse, 2003]. Further, these results have important implications for the future activity levels of soil microbial groups responsible for processing SOC pools in this forest.

[35] Microbial groups preferentially access different pools of SOM. Gram-positive bacteria generally access more complex C sources, while Gram-negative bacteria appear to use relatively labile, structurally simpler substrates [Bossio and Scow, 1995; Phillips et al., 2002; Kramer and Gleixner, 2008]. More specifically, actinomycetes (one type of Gram-positive bacteria) and fungi are relatively adept at degrading more recalcitrant SOM due both to the enzymes they are capable of producing and their physical structure [Rob et al., 1997; Fierer et al., 2003b; Schroter et al., 2003]. Given variation in how these groups of microbes access different pools of SOM, our findings suggest a mechanism for enhanced mineralization of relatively slow turnover SOC pools in the future with elevated $\mathrm{CO}_{2}$, congruent with an elevated $\mathrm{CO}_{2}$-induced priming effect suggested by several investigators [Xie et al., 2005; Carney et al., 2007; Langley et al., 2009]. If realized, such an effect on slow-turnover SOC would have important implications for SOC mineralization [Kuzyakov et al., 2000; Fontaine et al., 2007] given the large size of slow-turnover SOC pools.

[36] We did not observe a positive effect of elevated $\mathrm{CO}_{2}$ on incorporation of both substrates into both actinomycetes and fungi, highlighting potential substrate preferences of these groups and important deviations from generalizations about these groups' proclivity for relatively slow-turnover SOM. For example, glucose additions experienced greater flow into fungal PLFA with elevated $\mathrm{CO}_{2}$. Similar effects were not observed for the vanillin phenolic-C, a substrate often viewed as less labile than glucose [Bewley and Parkinson, 1986] given its conjugated aromatic structure, derivation from the decomposition of lignin, and decomposition by a more limited number of microorganisms relative to glucose. However, fungi are known to take up glucose [Chen and Hampp, 1993; Rinnan and Bääth, 2009]. Enhanced incorporation of vanillin phenolic-C into actinomycete PLFA with elevated $\mathrm{CO}_{2}$, with no analogous effect observed for glucose, is consistent with actinomycete use of relatively less labile substrates [Rob et al., 1997], particularly after it has been transformed into microbial byproducts, including microbial necromass [Ziegler et al., 2005]. These results impart the importance of employing multiple substrates when probing microbial community function in laboratory settings [Waldrop et al., 2004a; Rinnan and Bääth, 2009]. Moreover, they indicate that elevated $\mathrm{CO}_{2}$ can induce differing effects on the flows of multiple substrates through different microbial groupings in a forest soil.

[37] The negative response of actinomycete incorporation of vanillin phenolic- $\mathrm{C}$ to $\mathrm{N}$ additions observed here, regardless of $\mathrm{CO}_{2}$ level, suggests potential competitive interactions between microbial groups in these soils driven by some feature of soil $\mathrm{N}$ status affected by previous fertilization. Previous work at the site suggests that $\mathrm{N}$ additions result in relatively $\mathrm{N}$-rich organic inputs to the soil profile (J. Li et al., unpublished data, 2009), and greatly enhanced rates in the activity of urease, an extracellular enzyme associated with $\mathrm{N}$ acquisition [Billings and Ziegler, 2008]. Such data suggest that one effect of $\mathrm{N}$ amendments at this site has been to enhance soil $\mathrm{N}$ cycling; in conjunction with knowledge of the site's ecosystem-level $\mathrm{N}$ limitation [Oren et al., 2001], they further suggest that microbial communities in nonamended soils are $\mathrm{N}$ limited. One might thus 

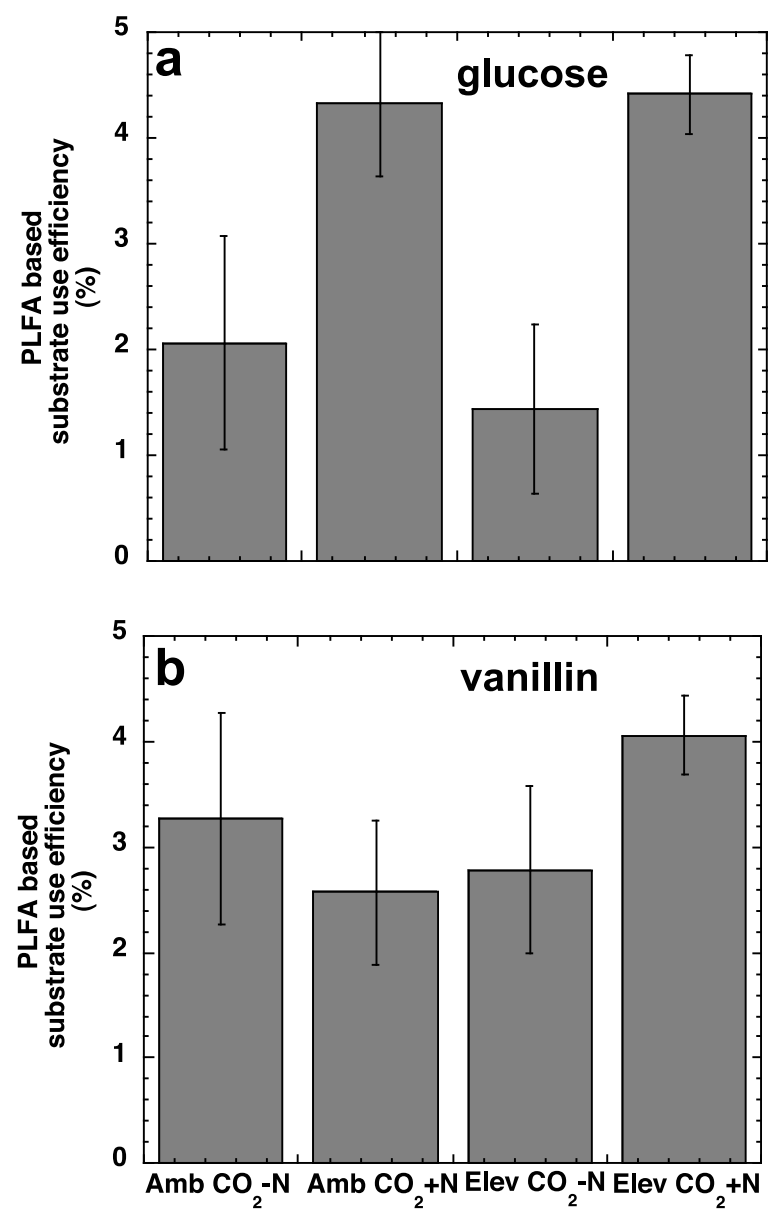

Figure 5. The phospholipid fatty acid (PLFA)-based substrate use efficiency for (a) the soils incubated with ${ }^{13} \mathrm{C}$ labeled glucose and (b) the soils incubated with the ${ }^{13} \mathrm{C}$ labeled vanillin phenolic-C. Phospholipid-based substrate use efficiency was calculated as the incorporation of substrate carbon (C) into the total soil PLFA pool as a percent of the sum of substrate- $\mathrm{C}$ incorporated into the total soil PLFA pool and $\mathrm{CO}_{2}$ respired. A significant $\mathrm{N}\left(\chi_{1,16}^{2}=\right.$ 44.02, $\mathrm{p}<0.0001)$, substrate $(\mathrm{S}) * \mathrm{~N}$ effect $\left(\chi_{1,16}^{2}=32.45\right.$, $\mathrm{p}<0.0001)$, and $\mathrm{CO}_{2} * \mathrm{~N}\left(\chi_{1,16}^{2}=13.43, \mathrm{p}=0.0048\right)$ on the overall PLFA-based SUE was observed. Specifically, the PLFA-based glucose use efficiency exhibited a significant $\left(\chi_{1,8}^{2}=22.04, \mathrm{p}<0.0001\right) \mathrm{N}$ effect, while vanillin phenolic-C use efficiency exhibited a significant $\left(\chi_{1,8}^{2}=11.99\right.$, $\mathrm{p}=0.0072) \mathrm{CO}_{2} * \mathrm{~N}$ effect.

expect an increase in the competitive advantages of copiotrophic microbial groups such as Gram-negative bacteria [Paul and Clark, 1996] in fertilized soils [Borga et al., 1994; Saetre and Bääth, 2000], with reciprocal declines in the activity level of more oligotrophic microbial groups such as actinomycetes. We did not, however, observe a positive effect of $\mathrm{N}$ amendments on vanillin phenolic-C use by Gram-negative bacteria, suggesting that competition between actinomycetes and Gram-negative bacteria was not an important feature governing vanillin use in these incubations. Gram-negative bacteria are typically the most abundant component in rhizosphere soil [Elo et al., 2000; Soderberg et al., 2004] suggesting this lack of a positive response to $\mathrm{N}$ may have resulted from the lack of plant-soil interactions in these incubations. In the field, however, where plant-soil interactions are intact, $\mathrm{N}$ addition had a significant, positive effect on Gram-negative bacterial uptake of recently formed photosynthate [Billings and Ziegler, 2008], a reciprocal effect of what we observed for actinomycetes during these incubations. Together, these studies suggest that mitigation of $\mathrm{N}$ limitation with $\mathrm{N}$ amendments, even when differences in inorganic $\mathrm{N}$ availability are no longer evident, can promote copiotrophic access to labile substrates, with oligotrophic organisms such as actinomycetes experiencing a relative decline in their activity.

\subsection{The Potential Impact of Elevated $\mathrm{CO}_{2}$ and $\mathrm{N}$ Availability on Microbial Substrate Use Efficiency}

[38] Microorganisms are key agents in determining if SOC substrates remain intact, are transformed into biomass or other SOC compounds, or are mineralized into $\mathrm{CO}_{2}$ [Nannipieri et al., 2003]. Ultimately the composition of organic matter inputs and microbial community structure, as well as environmental conditions such as nutrient and water availability and temperature, combine to regulate the efficiency with which microorganisms use available resources. The proportion of the organic matter used for biomass production can later reside in pools of SOC transformed by microbial processing. These transformed compounds can be relatively labile, such as simple $\mathrm{C}$ compounds lysed upon cell death or precursors to humic substances, which represent relatively slow-turnover SOC pools, such as peptidoglycan and chitin [Paul and Van Veen, 1978; Martin and Haider, 1986]. The efficiency with which microorganisms incorporate organic $\mathrm{C}$-substrates into their biomass versus releasing it as $\mathrm{CO}_{2}$ thus is one determinant of the SOC ultimately retained within a soil profile.

[39] Consistent with a greater $\mathrm{C}: \mathrm{N}$ ratio of mineralizable substrates in elevated $\mathrm{CO}_{2}$ soils observed at this site [Billings and Ziegler, 2005], our results indicate that PLFAbased SUE was dependent on $\mathrm{CO}_{2}$ treatment, and also regulated by soil $\mathrm{N}$ status. For example, unfertilized soils exhibited lower retention of vanillin in microbial PLFA in elevated $\mathrm{CO}_{2}$ soils relative to soils with $\mathrm{N}$ amendments. It is possible that microbes in the unfertilized soils may have allocated more substrate-C incorporated into storage molecules such as neutral lipids [Bääth, 2003; Rinnan et al., 2009] not measured here. The higher substrate- $C$ respired in the unfertilized soils, however, is consistent with reduced substrate- $\mathrm{C}$ retention in the unfertilized soils regardless of the potential for more substrate allocation into storage lipids, suggesting that stoichiometry of available resources and microbial demand [Sinsabaugh et al., 2008] governs these results. Stoichiometric theory predicts that a relatively high $\mathrm{C}: \mathrm{N}$ ratio of available substrates will result in less efficient use of $\mathrm{C}$ by microbial communities. The significant $\mathrm{CO}_{2} * \mathrm{~N}$ interaction effect on PLFA-based SUE for vanillin suggests that if $\mathrm{N}$ limitation at the ecosystem level and, presumably, for soil microorganisms, is enhanced with elevated $\mathrm{CO}_{2}$ [Luo et al., 2004; Finzi et al., 2006], substrates similar in structure to vanillin, a product of lignin degradation, may be incorporated into biomass to a lesser degree and used for $R_{h}$ to a greater degree. This represents one potential mechanism explaining increased soil respiration in the field at this site 
with elevated $\mathrm{CO}_{2}$ [DeLucia et al., 1999; Andrews and Schlesinger, 2001; Hamilton et al., 2002] and its apparent regulation by $\mathrm{N}$ availability [Butnor et al., 2003] and, more specifically, by soil microorganisms in isolation from autotrophic respiration [Billings and Ziegler, 2008].

[40] In contrast to the results for vanillin, we observed an effect of $\mathrm{N}$ amendments on glucose-derived PLFA-based SUE with no interaction effect of elevated $\mathrm{CO}_{2}$. The significantly higher respiration in the glucose amended soils relative to the controls suggest that the addition of a highly bioavailable substrate likely induced relative $\mathrm{N}$ limitation, consistent with the stoichiometric needs of microorganisms [Sinsabaugh et al., 2008]. If so, any potential $\mathrm{CO}_{2}$ effect in these soils may have been masked by stimulation of microbial activity with glucose additions, and overshadowed by $\mathrm{N}$ amendment effects likely enhanced by glucoseimposed exacerbation of $\mathrm{N}$ limitation. These results demonstrate the important influence of potential microbial $\mathrm{N}$ limitation with elevated $\mathrm{CO}_{2}$ on the fate of enhanced labile $\mathrm{C}$ inputs such as root exudates, which experience declines on a mass-specific basis with $\mathrm{N}$ amendments at this site [Phillips et al., 2009].

[41] Differences in the influence of elevated $\mathrm{CO}_{2}$ and $\mathrm{N}$ on PLFA-based SUE for the two substrates also reflects varied microbial responses to glucose and vanillin availability [Schimel and Gulledge, 1998; Phillips et al., 2002; Rinnan and Bääth, 2009], and provide some insight into what may drive microbial processing of substrates with varying lability in these soils. The significant effect of $\mathrm{N}$ on glucose incorporation into all four microbial PLFA groupings assessed (Gram-negative, Gram-positive bacteria, actinomycetes, and fungi) suggests that many populations within this soil's microbial community were influenced by the altered stoichiometry induced by glucose addition, consistent with the utility of glucose for a wide cross section of microbial heterotrophs [Anderson and Domsch, 1978]. In contrast, only actinomycete PLFA exhibited an effect of soil $\mathrm{N}$ status on vanillin phenolic-C incorporation. This is consistent with studies that suggest the importance of actinomycetes in mineralizing less labile substrates [McCarthy and Williams, 1992; Rob et al., 1997], and emphasizes the importance of providing substrates of varying structural complexity to assess responses of multiple microbial groups to experimental treatments.

\subsection{Regulation of Soil Organic Matter Fate With Elevated $\mathrm{CO}_{2}$ by N Status: Hypotheses for Future Research}

[42] Without the benefit of truly long-term soil experiments that permit direct observation of changes in pools and dynamics of fast- and slow-turnover SOC, we are limited in how to experimentally deduce the effects of perturbations on these pools and the microbial communities that transform them. Though the application of isotopically labeled $\mathrm{C}$ compounds to soils permits inferences about activity levels of multiple microbial groups, our inferences about future dynamics of slow-turnover SOC from such studies are limited by the restricted availability of relatively recalcitrant, ${ }^{13} \mathrm{C}$-labeled substrates available for experimentation. Vanillin, used here, is a byproduct of lignin degradation and is apparently accessed by many microorganisms at a slower rate than glucose, but is nevertheless far less structurally complex than many of the stable SOC compounds found in situ. However, these and related studies can serve a critical role by guiding the scientific community in the development of hypotheses for future research, when it becomes more feasible to directly measure the influence of elevated $\mathrm{CO}_{2}$ and the enhanced $\mathrm{N}$ limitation likely associated with it on SOC cycling. We offer two hypotheses based on our observations of how legacy effects of field $\mathrm{N}$ amendments govern microbial responses to elevated $\mathrm{CO}_{2}$.

[43] 1. Continued increases in atmospheric $\mathrm{CO}_{2}$ and the ecosystem-level $\mathrm{N}$ limitation associated with it will result in progressively enhanced activity rates of actinomycetes and some fungal populations in forest soils.

[44] 2. These perturbations will further result in: (1) greater relative abundances of compounds derived from these groups' cell walls such as chitin and peptidoglycan, which can serve as precursors to stabilized SOM; and (2) lower relative abundances of slow-turnover SOC pools subjected to greater actinomycete and fungal processing.

[45] Testing these hypotheses will become increasingly feasible after multiple decades of exposure to elevated $\mathrm{CO}_{2}$, imposed either experimentally or via anthropogenic alterations of Earth's atmospheric composition.

[46] The first hypothesis is a direct inference from the current study, as well as our previous work [Billings and Ziegler, 2005, 2008]. Over time, activity rates of actinomycetes and fungi may be assessed even in experimental plots no longer receiving supplemental $\mathrm{CO}_{2}$. For example, at Duke FACE, SOC pools currently exhibit varying levels of ${ }^{13} \mathrm{C}$ label incorporation [Lichter et al., 2005]. We can exploit this knowledge and track the relatively depleted $\delta^{13} \mathrm{C}$ signature of recently formed photosynthate as it is transformed within the site's soil profiles long after $\mathrm{CO}_{2}$ treatments have ceased. Presumably, some of that label will become increasingly incorporated into more slow-turnover SOC pools over time, and into the microbial populations responsible for those transformations. Such studies are not perfect (we lack decades-long, in situ experiments and proper controls), but tracking the fate of the field-applied ${ }^{13} \mathrm{C}$ label could be an important complement to our knowledge of microbial processing of slow-turnover SOC in these forest soils.

[47] The second hypothesis reflects two processes with potentially counteracting influences on pool sizes of slowturnover SOC, with unknown net effects. One might predict an increase in the relative abundance of slow-turnover SOC as inputs of peptidoglycan and chitin (important precursors to slow-turnover SOC pools; Paul and Van Veen, 1978; Martin and Haider, 1986; Guggenberger et al., 1999) within soil profiles are enhanced, due to an increase in the activity rates and thus cell wall production of actinomycetes and fungi, respectively [Sollins et al., 1996; Simpson et al., 2007]. The other process reflects the substrate choice of actinomycetes and fungi; though these organisms may help produce relatively slow-turnover SOC via their cell wall structures, they also are adept at accessing such pools to obtain energy and nutrients [McCarthy and Williams, 1992; Rob et al., 1997; Fierer et al., 2003b].

[48] Currently, ecosystem scientists have difficulty predicting SOC stocks in a high $\mathrm{CO}_{2}$ world. We are uncertain about the relative magnitudes of NPP enhancements versus soil respiration with elevated $\mathrm{CO}_{2}$. Further, we are unable to 
predict whether these enhanced $\mathrm{C}$ fluxes will be sustained over the long-term. This study clarifies two potentially counteractive mechanisms that can influence soil respiratory responses to elevated $\mathrm{CO}_{2}$ and the size of relatively slowturnover SOC stocks. First, enhanced inputs to those pools may occur via increased relative abundances of microbial cell wall structures that are precursors of stabilized SOM. Second, increased degradation of relatively slow-turnover SOC pools may occur via those same organisms. Our work emphasizes the need to couple assessments of the chemical and isotopic composition of SOC [Billings et al., 2010] with radiocarbon measurements of multiple SOC pools to assess their age [Trumbore, 2009]. Such future explorations elucidating the linkages among active microbial groups and SOC chemical composition and age will be critical for predicting SOC dynamics in a high $\mathrm{CO}_{2}$ world.

[49] Acknowledgments. This research was supported by the Office of Science (BER) Program, U.S. Department of Energy grant DE-FG0295ER62083, the U.S. Department of Energy's National Institute of Climate Change Research (NICCR) grant DE-FC02-03ER63613 (awarded from the National Institute for Global Environmental Change Southeast Regional Center (NIGEC SERC)), the Natural Sciences and Engineering Research Council of Canada (NSERC), and the Canada Research Chair program. We thank Erik Pollock, Laurel Haavik, Andrea Kopecky, David Lyon, Tom Millican, Glenn Piercey, Jeff Pippen, Ryan Rastok, Alexis Reed, Vaughn Salisbury, Lisa Tiemann, and Guihong Zhang for assistance in the field and laboratory. Thanks also go to David Schneider for his assistance with statistical analyses.

\section{References}

Abraham, W.-R., and C. Hesse (2003), Isotope fractionations in the biosynthesis of cell components by different fungi: A basis for environmental carbon flux studies, FEMS Microbiol. Ecol., 46, 121-128, doi:10.1016/ S0168-6496(03)00203-4.

Abrajano, T. A., Jr., D. E. Murphy, J. Fang, P. Comet, and J. M. Brooks (1994), ${ }^{13} \mathrm{C} /{ }^{12} \mathrm{C}$ ratios in individual fatty acids of marine mytilids with and without bacterial symbionts, Org. Geochem., 21, 611-617, doi:10. 1016/0146-6380(94)90007-8.

Agren, G. I., E. Bosatta, and A. H. Magill (2001), Combining theory and experiment to understand effects of inorganic nitrogen on litter decomposition, Oecologia, 128, 94-98, doi:10.1007/s004420100646.

Anderson, J. P. E., and K. H. Domsch (1978), Physiological method for quantitative measurement of microbial biomass in soils, Soil Biol. Biochem., 10, 215-221, doi:10.1016/0038-0717(78)90099-8.

Andrews, J. A., and W. H. Schlesinger (2001), Soil $\mathrm{CO}_{2}$ dynamics, acidification, and chemical weathering in a temperate forest with experimental $\mathrm{CO}_{2}$ enrichment, Global Biogeochem. Cycles, 15, 149-162, doi:10.1029 2000GB001278.

Bääth, E. (2003), The use of neutral lipid fatty acids to indicate the physiological conditions of soil fungi, Microb. Ecol., 45, 373-383, doi:10.1007/ s00248-003-2002-y.

Benner, R., M. Fogel, E. K. Sprague, and R. Hodson (1987), Depletion of ${ }^{13} \mathrm{C}$ in lignin and its implications for stable isotope studies, Nature, 329, 708-710, doi:10.1038/329708a0.

Bernhardt, E. S., J. J. Barber, J. S. Pippen, L. Taneva, J. A. Andrews, and W. H. Schlesinger (2006), Long-term effects of free air $\mathrm{CO}_{2}$ enrichment (FACE) on soil respiration, Biogeochemistry, 77, 91-116, doi:10.1007/ s10533-005-1062-0.

Bewley, R. J. F., and D. Parkinson (1986), Monitoring the impact of acid deposition on the soil microbiota, using glucose and vanillin decomposition, Water Air Soil Pollut., 27, 57-68, doi:10.1007/BF00464769.

Billings, S. A., and S. E. Ziegler (2005), Linking microbial activity and soil organic matter transformations in forest soils under elevated $\mathrm{CO}_{2}$, Global Change Biol., 11, 203-212, doi:10.1111/j.1365-2486.2005.00909.x.

Billings, S. A., and S. E. Ziegler (2008), Altered patterns of soil carbon substrate usage and heterotrophic respiration in a pine forest with elevated $\mathrm{CO}_{2}$ and $\mathrm{N}$ fertilization, Global Change Biol., 14, 1025-1036, doi:10.1111/j.1365-2486.2008.01562.x.

Billings, S. A., J. Lichter, S. E. Ziegler, B. A. Hungate, and D. B. Richter (2010), A call to investigate drivers of soils organic matter retention vs. mineralization in a high $\mathrm{CO}_{2}$ world, Soil Biol. Biochem., 42, 665-668, doi:10.1016/j.soilbio.2010.01.002.

Borga, P., M. Nilsson, and A. Tunlid (1994), Bacterial communities in peat in relation to botanical composition as revealed by phospholipid fattyacid analysis, Soil Biol. Biochem., 26, 841-848, doi:10.1016/00380717(94)90300-X.

Boschker, H. T. S., and J. J. Middelburg (2002), Stable isotopes and biomarkers in microbial ecology, FEMS Microbiol. Ecol., 40, 85-95, doi:10.1111/j.1574-6941.2002.tb00940.x.

Bossio, D. A., and K. M. Scow (1995), Impact of carbon and flooding on the metabolic diversity of microbial communities in soils, Appl. Environ. Microbiol., 61, 4043-4050.

Butnor, J. R., K. H. Johnsen, R. Oren, and G. G. Katul (2003), Reduction of forest floor respiration by fertilization on both carbon dioxide-enriched and reference 17-year-old loblolly pine stands, Global Change Biol., 9, 849-861, doi:10.1046/j.1365-2486.2003.00630.x

Carney, K. M., B. A. Hungate, B. G. Drake, and J. P. Megonigal (2007), Altered soil microbial community at elevated $\mathrm{CO}_{2}$ leads to loss of soil carbon, Proc. Natl. Acad. Sci. U. S. A., 104, 4990-4995, doi:10.1073/ pnas.0610045104

Chen, X. Y., and R. Hampp (1993), Sugar uptake by protoplasts of the ectomycorrhizal fungus, Amanita muse aria (L. ex fr.) Hooker, New Phytol., 125, 601-608, doi:10.1111/j.1469-8137.1993.tb03909.x.

Crawford, R. L. (1981), Lignin Biodegradation and Transformation, 154 pp., John Wiley, New York.

Dec, J., K. Haider, and J. M. Bollag (2001), Decarboxylation and demethoxylation of naturally occurring phenols during coupling reactions and polymerization, Soil Sci., 166, 660-671, doi:10.1097/ 00010694-200110000-00002.

del Giorgio, P. A., and J. J. Cole (1998), Bacterial growth efficiency in natural aquatic systems, Annu. Rev. Ecol. Syst., 29, 503-541, doi:10. 1146/annurev.ecolsys.29.1.503

DeLucia, E. H., et al. (1999), Net primary production of a forest ecosystem with experimental $\mathrm{CO}_{2}$ enrichment, Science, 284, 1177-1179, doi:10.1126/science. 284.5417.1177.

Dobbs, F. C., and R. H. Findlay (1993), Analysis of microbial lipids to determine biomass and detect the response of sedimentary microorganisms to disturbance, in Current Methods in Aquatic Microbial Ecology, edited by P. F. Kemp et al., pp. 347-358, Lewis, Baton Rouge, La.

Elo, S., L. Maunuksela, M. Salkinoja-Salonen, A. Smolander, and K. Haahtela (2000), Humus bacteria of Norway spruce stands: Plant growth promoting properties and birch, red fescue and alder colonizing capacity, FEMS Microbiol. Ecol., 31, 143-152, doi:10.1111/j.15746941.2000.tb00679.x

Federle, T. W. (1986), Microbial distribution in soil-New techniques, in Perspectives in Microbial Ecology, edited by F. Megusar and M. Gantar, pp. 493-498, Slovene Soc. for Microbiol., Ljubljana, Slovenia.

Fierer, N., A. S. Allen, J. P. Schimel, and P. A. Holden (2003a), Controls on microbial $\mathrm{CO} 2$ production: A comparison of surface and subsurface soil horizons, Global Change Biol., 9, 1322-1332, doi:10.1046/j.13652486.2003.00663.x.

Fierer, N., J. P. Schimel, and P. A. Holden (2003b), Variations in microbial community composition through two soil depth profiles, Soil Biol. Biochem., 35, 167-176, doi:10.1016/S0038-0717(02)00251-1.

Findlay, R. H. (2007), Determination of microbial community structure using phospholipid fatty acid profiles, in Molecular Microbial Ecology Manual, edited by G. A. Kowalchuk et al., pp. 983-1003, Springer, New York.

Findlay, R. H., and F. C. Dobbs (1993), Quantitative description of microbial communities using lipid analysis, in Current Methods in Aquatic Microbial Ecology, edited by P. F. Kemp et al., pp. 271-284, Lewis, Boca Raton, Fla.

Finzi, A. C., et al. (2006), Progressive nitrogen limitation of ecosystem processes under elevated $\mathrm{CO}_{2}$ in a warm-temperate forest, Ecology, 87, 15-25, doi:10.1890/04-1748.

Finzi, A. C., et al. (2007), Increases in nitrogen uptake rather than nitrogenuse efficiency support higher rates of temperate forest productivity under elevated $\mathrm{CO}_{2}$, Proc. Natl. Acad. Sci. U. S. A., 104, 14,014-14,019, doi:10.1073/pnas.0706518104

Fontaine, M., R. Aerts, K. Ozkan, A. Mert, S. Gulsoy, H. Suel, M. Waelkens, and B. Muys (2007), Elevation and exposition rather than soil types determine communities and site suitability in Mediterranean mountain forests of southern Anatolia, Turkey, For. Ecol. Manage., 247, 18-25, doi:10.1016/ j.foreco.2007.04.021.

Frostegärd, A., and E. Bääth (1996), The use of phospholipid fatty acid analysis to estimate bacterial and fungal biomass in soil, Biol. Fertil. Soils, 22, 59-65, doi:10.1007/BF00384433.

Frostegärd, A., E. Bääth, and A. Tunlid (1993a), Shifts in the structure of soil microbial communities in limed forests as revealed by phospholipid 
fatty-acid analysis, Soil Biol. Biochem., 25, 723-730, doi:10.1016/00380717(93)90113-P.

Frostegärd, A., A. Tunlid, and E. Bääth (1993b), Phospholipid fatty-acid composition, biomass, and activity of microbial communities from 2 soil types experimentally exposed to different heavy-metals, Appl. Environ. Microbiol., 59, 3605-3617.

Guggenberger, G., S. D. Frey, J. Six, K. Paustian, and E. T. Elliott (1999), Bacterial and fungal cell-wall residues in conventional and no-tillage agroecosystems, Soil Sci. Soc. Am. J., 63, 1188-1198, doi:10.2136/ sssaj1999.6351188x.

Hamilton, J. G., E. H. DeLucia, K. George, S. L. Naidu, A. C. Finzi, and W. H. Schlesinger (2002), Forest carbon balance under elevated $\mathrm{CO}_{2}$, Oecologia, 131, 250-260, doi:10.1007/s00442-002-0884-x.

Hayes, J. M. (2001), Fractionation of carbon and hydrogen isotopes in biosynthetic processes, in Reviews in Mineralology and Geochemistry, edited by J. W. Valley and D. R. Cole, pp. 225-277, Mineral. Soc. of Am., Blacksberg, Va.

Hoffmann, J. P. (2004), Generalized Linear Models: An Applied Approach, 1st ed., 204 pp., Pearson, Boston, Mass.

Hogberg, M. N., P. Hogberg, and D. D. Myrold (2007), Is microbial community composition in boreal forest soils determined by $\mathrm{pH}, \mathrm{C}-$ to- $\mathrm{N}$ ratio, the trees, or all three?, Oecologia, 150, 590-601, doi:10.1007/ s00442-006-0562-5.

Holland, E. A., and D. C. Coleman (1987), Litter placement effects on microbial and organic-matter dynamics in an agroecosystem, Ecology, 68, 425-433, doi:10.2307/1939274.

Hoosbeek, M. R., Y. T. Li, and G. E. Scarascia-Mugnozza (2006), Free atmospheric $\mathrm{CO}_{2}$ enrichment (FACE) increased labile and total carbon in the mineral soil of a short rotation Poplar plantation, Plant Soil, 281, 247-254, doi:10.1007/s11104-005-4293-x.

Huang, J. G., Y. Bergeron, B. Denneler, F. Berninger, and J. Tardif (2007), Response of forest trees to increased atmospheric $\mathrm{CO}_{2}$, Crit. Rev. Plant Sci., 26, 265-283, doi:10.1080/07352680701626978.

Kramer, C., and G. Gleixner (2008), Soil organic matter in soil depth profiles: Distinct carbon preferences of microbial groups during carbon transformation, Soil Biol. Biochem., 40, 425-433, doi:10.1016/j.soilbio.2007.09.016.

Kuzyakov, Y., J. K. Friedel, and K. Stahr (2000), Review of mechanisms and quantification of priming effects, Soil Biol. Biochem., 32, 1485 1498, doi:10.1016/S0038-0717(00)00084-5.

Langley, J. A., D. C. McKinley, A. A. Wolf, B. A. Hungate, B. G. Drake, and J. P. Megonigal (2009), Priming depletes soil carbon and releases nitrogen in a scrub-oak ecosystem exposed to elevated $\mathrm{CO}_{2}$, Soil Biol. Biochem., 41, 54-60, doi:10.1016/j.soilbio.2008.09.016.

Lichter, J., S. H. Barron, C. E. Bevacqua, A. C. Finzli, K. E. Irving, E. A. Stemmler, and W. H. Schlesinger (2005), Soil carbon sequestration and turnover in a pine forest after six years of atmospheric $\mathrm{CO}_{2}$ enrichment, Ecology, 86, 1835-1847, doi:10.1890/04-1205.

Lindsey, J. K. (1997), Applying Generalized Linear Models, 271 pp., Springer, New York.

Luo, Y., et al. (2004), Progressive nitrogen limitation of ecosystem responses to rising atmospheric carbon dioxide, BioScience, 54 731-739, doi:10.1641/0006-3568(2004)054[0731:PNLOER]2.0.CO;2.

Maier, C. A., and L. W. Kress (2000), Soil $\mathrm{CO}_{2}$ evolution and root respiration in 11 year-old loblolly pine (Pinus taeda) plantations as affected by moisture and nutrient availability, Can. J. For. Res., 30, 347-359, doi:10.1139/cjfr-30-3-347.

Martin, J. P., and K. Haider (1986), Influence of mineral colloids on turnover rates of soil organic carbon, in Interactions of Soil Minerals With Natural Organics and Microbes, edited by P. M. Huang and M. Schnitzer, pp. 283-304, Soil Soc. of Am., Madison, Wis.

Matamala, R., and W. H. Schlesinger (2000), Effects of elevated atmospheric $\mathrm{CO}_{2}$ on fine root production and activity in an intact temperate forest ecosystem, Global Change Biol., 6, 967-979, doi:10.1046/ j.1365-2486.2000.00374.x.

Matamala, R., M. A. Gonzalez-Meler, J. D. Jastrow, R. J. Norby, and W. H. Schlesinger (2003), Impacts of fine root turnover on forest NPP and soil C sequestration potential, Science, 302, 1385-1387, doi:10 1126/science. 1089543 .

McCarthy, A. J., and S. T. Williams (1992), Actinomycetes as agents of biodegradation in the environment-A review, Gene, 115, 189-192, doi:10.1016/0378-1119(92)90558-7.

McClaugherty, C. A., J. D. Aber, and J. M. Melillo (1982), The role of fine roots in the organic-matter and nitrogen budgets of 2 forested ecosystems, Ecology, 63, 1481-1490, doi:10.2307/1938874.

Nannipieri, P., J. Ascher, M. T. Ceccherini, L. Landi, G. Pietramellara, and G. Renella (2003), Microbial diversity and soil functions, Eur. J. Soil Sci., 54, 655-670, doi:10.1046/j.1351-0754.2003.0556.x.
Olsson, P. A. (1999), Signature fatty acids provide tools for determination of the distribution and interactions of mycorrhizal fungi in soil, FEMS Microbiol. Ecol., 29, 303-310, doi:10.1111/j.1574-6941.1999.tb00621.x. Oren, R., et al. (2001), Soil fertility limits carbon sequestration by forest ecosystems in a $\mathrm{CO}_{2}$-enriched atmosphere, Nature, 411, 469-472, doi:10.1038/35078064.

Parrent, J. L., and R. Vilgalys (2007), Biomass and compositional responses of ectomycorrhizal fungal hyphae to elevated $\mathrm{CO}_{2}$ and nitrogen fertilization, New Phytol., 176, 164-174, doi:10.1111/j.1469-8137. 2007.02155.x

Parrent, J. L., W. F. Morris, and R. Vilgalys (2006), $\mathrm{CO}_{2}$-enrichment and nutrient availability alter ectomycorrhizal fungal communities, Ecology, 87, 2278-2287, doi:10.1890/0012-9658(2006)87[2278:CANAAE]2.0. $\mathrm{CO} ; 2$.

Paul, E. A., and F. E. Clark (1996), Soil Microbiology and Biochemistry, 340 pp., Academic, Toronto, Ont., Canada.

Paul, E. A., and H. Van Veen (1978), The use of tracers to determine the dynamic nature of organic matter, Trans. 11th Int. Congr. Soil Sci., 3, 61-102.

Pelz, O., C. Hesse, M. Tesar, R. B. Coffin, and W.-R. Abraham (1997), Development of methods to measure carbon isotope ratios of bacterial biomarkers in the environment, Isotopes Environ. Health Stud., 33, 131-144.

Phillips, R. L., D. R. Zak, W. E. Holmes, and D. C. White (2002), Microbial community composition and function beneath temperate trees exposed to elevated atmospheric carbon dioxide and ozone, Oecologia, 131, 236-244, doi:10.1007/s00442-002-0868-x.

Phillips, R. P., E. S. Bernhardt, and W. H. Schlesinger (2009), Elevated $\mathrm{CO}_{2}$ increases root exudation from loblolly pine (Pinus taeda) seedlings as an N-mediated response, Tree Physiol., 29, 1513-1523, doi:10.1093/ treephys/tpp083.

Pinkart, H. C., R. Devereux, and P. J. Chapman (1998), Rapid separation of microbial lipids using solid phase extraction columns, J. Microbiol. Methods, 34, 9-15, doi:10.1016/S0167-7012(98)00060-8.

Pregitzer, K., W. Loya, M. Kubiske, and D. Zak (2006), Soil respiration in northern forests exposed to elevated atmospheric carbon dioxide and ozone, Oecologia, 148, 503-516, doi:10.1007/s00442-006-0381-8.

Pritchard, S. G., A. E. Strand, M. L. McCormack, M. A. Davis, A. C. Finz, R. B. Jackson, R. Matamala, H. H. Rogers, and R. Oren (2008), Fine root dynamics in a loblolly pine forest are influenced by free-air- $\mathrm{CO}_{2}$-enrichment: A six-year-minirhizotron study, Global Change Biol., 14, 588 602, doi:10.1111/j.1365-2486.2007.01523.x.

Ribbons, D. W., and Y. Ohta (1970), Uncoupling of electron transport from oxygenation in mono-oxygenase, orcinol hydroxylase, FEBS Lett., 12, 105, doi:10.1016/0014-5793(70)80574-9.

Ringelberg, D. B., et al. (1989), Validation of signature polarlipid fatty acids biomarkers for alkane-utilizing bacteria in soils and subsurface aquifer materials, FEMS Microbiol. Ecol., 62, 39-50, doi:10.1111/ j.1574-6968.1989.tb03656.x.

Rinnan, R., and E. Bääth (2009), Differential utilization of carbon substrates by bacteria and fungi in tundra soil, Appl. Environ. Microbiol. 75, 3611-3620, doi:10.1128/AEM.02865-08.

Rinnan, R., S. Stark, and A. Tolvanen (2009), Responses of vegetation and soil microbial communities to warming and simulated herbivory in a subarctic heath, J. Ecol., 97, 788-800, doi:10.1111/j.1365-2745. 2009.01506.x

Rob, A., M. Hernandez, A. S. Ball, M. Tuncer, M. E. Arias, and M. T. Wilson (1997), Production and partial characterization of extracellular peroxidases produced by Streptomyces avermitilis UAH30, Appl. Biochem. Biotechnol., 62, 159-174, doi:10.1007/BF02787992.

Saetre, P., and E. Bääth (2000), Spatial variation and patterns of soil microbial community structure in a mixed spruce-birch stand, Soil Biol. Biochem., 32, 909-917, doi:10.1016/S0038-0717(99)00215-1.

Schimel, J. P., and J. Gulledge (1998), Microbial community structure and global trace gases, Global Change Biol., 4, 745-758, doi:10.1046/j.13652486.1998.00195.x.

Schlesinger, W. H., and J. Lichter (2001), Limited carbon storage in soil and litter of experimental forest plots under increased atmospheric $\mathrm{CO}_{2}$, Nature, 411, 466-469, doi:10.1038/35078060.

Schlesinger, W. H., et al. (2006), The Duke Forest FACE experiment: $\mathrm{CO}_{2}$ enrichment of a loblolly pine forest, in Managed Ecosystems and $\mathrm{CO}_{2}$ Case Studies, Processes, and Prospectives, Ecological Studies, edited by J. Nosberger et al., pp. 197-212, Springer, Berlin.

Schroter, D., V. Wolters, and P. C. De Ruiter (2003), C and N mineralisation in the decomposer food webs of a European forest transect, Oikos, 102, 294-308, doi:10.1034/j.1600-0579.2003.12064.x.

Silfer, J. A., M. H. Engel, S. A. Macko, and E. J. Jumeau (1991), Stable carbon isotope analysis of amino acid enantiomers by conventional isotope ratio mass spectrometry and combined gas chromatography-isotope 
ratio mass spectrometry, Anal. Chem., 63, 370-374, doi:10.1021/ ac00004a014.

Simpson, A. J., G. X. Song, E. Smith, B. Lam, E. H. Novotny, and M. H. B. Hayes (2007), Unraveling the structural components of soi humin by use of solution-state nuclear magnetic resonance spectroscopy, Environ. Sci. Technol., 41, 876-883, doi:10.1021/es061576c.

Sinsabaugh, R. L., et al. (2008), Stoichiometry of soil enzyme activity at global scale, Ecol. Lett., 11, 1252-1264.

Soderberg, K. H., A. Probanza, A. Jumpponen, and E. Bääth (2004), The microbial community in the rhizosphere determined by community-level physiological profiles (CLPP) and direct soil- and cfu-PLFA techniques, Appl. Soil Ecol., 25, 135-145, doi:10.1016/j.apsoil.2003.08.005.

Sollins, P., P. Homann, and B. A. Caldwell (1996), Stabilization and destabilization of soil organic matter: Mechanisms and controls, Geoderma, 74, 65-105, doi:10.1016/S0016-7061(96)00036-5.

Sparks, J. P., J. Walker, A. Turnipseed, and A. Guenther (2008), Dry nitrogen deposition estimates over a forest experiencing free air $\mathrm{CO}_{2}$ enrichment, Global Change Biol., 14, 768-781, doi:10.1111/j.13652486.2007.01526.x

Teklay, T., A. Nordgren, G. Nyberg, and A. Malmer (2007), Carbon mineralization of leaves from four Ethiopian agroforestry species under laboratory and field conditions, Appl. Soil Ecol., 35, 193-202, doi:10.1016/ j.apsoil.2006.04.002.

Thiet, R. K., S. D. Frey, and J. Six (2006), Do growth yield efficiencies differ between soil microbial communities differing in fungal: Bacteria ratios? Reality check and methodological issues, Soil Biol. Biochem. 38, 837-844, doi:10.1016/j.soilbio.2005.07.010.

Trumbore, S. (2009), Radiocarbon and soil carbon dynamics, Annu. Rev. Earth Planet. Sci., 37, 47-66, doi:10.1146/annurev.earth.36. 031207.124300

Tunlid, A., and D. C. White (1992), Biochemical analysis of biomass, community structure, nutritional status, and metabolic activity of microbial communities in soil, in Soil Biochemistry, edited by G. Stotzky and J.-M. Bollag, pp. 229-262, Marcel Decker, New York.

Tunlid, A., H. Ek, G. Westerdahl, and G. Odham (1987), Determination of ${ }^{13} \mathrm{C}$-enrichment in bacterial fatty acids using chemical ionization mass spectrometry with negative ion detection, J. Microbiol. Methods, 7 , 77-89, doi:10.1016/0167-7012(87)90028-5.

Waldrop, M. P., and M. K. Firestone (2004), Microbial community utilization of recalcitrant and simple carbon compounds: Impact of oak- woodland plant communities, Oecologia, 138, 275-284, doi:10.1007/ s00442-003-1419-9.

Waldrop, M. P., D. R. Zak, and R. L. Sinsabaugh (2004a), Microbial community response to nitrogen deposition in northern forest ecosystems, Soil Biol. Biochem., 36, 1443-1451, doi:10.1016/j.soilbio.2004.04.023.

Waldrop, M. P., D. R. Zak, R. L. Sinsabaugh, M. Gallo, and C. Lauber (2004b), Nitrogen deposition modifies soil carbon storage through changes in microbial enzymatic activity, Ecol. Appl., 14, 1172-1177, doi:10.1890/03-5120.

Waring, R. H., and W. H. Schlesinger (1985), Forest Ecosystems: Concepts and Management, Academic, San Diego, Calif.

White, D. C., and R. H. Findlay (1988), Biochemical markers for measurement of predation effects on the biomass, community structure, nutritional status, and metabolic activity of microbial biofilms, Hydrobiologia, 159, 119-132.

White, D. C., and D. B. Ringelberg (1998), Signature lipid biomarker analysis, in Techniques in Microbial Ecology, edited by R. S. Burlage et al. pp. 255-272, Oxford Univ. Press, New York.

White, D. C., J. O. Stair, and D. B. Ringelberg (1996), Quantitative comparisons of in situ microbial biodiversity by signature biomarker analysis, J. Ind. Microbiol., 17, 185-196, doi:10.1007/BF01574692.

Xie, Z. B., G. Cadisch, G. Edwards, E. M. Baggs, and H. Blum (2005), Carbon dynamics in a temperate grassland soil after 9 years exposure to elevated $\mathrm{CO}_{2}$ (Swiss FACE), Soil Biol. Biochem., 37, 1387-1395, doi:10.1016/j.soilbio.2004.12.010.

Zak, D. R., W. E. Holmes, A. C. Finzi, R. J. Norby, and W. H. Schlesinger (2003), Soil nitrogen cycling under elevated $\mathrm{CO}_{2}$ : A synthesis of forest face experiments, Ecol. Appl., 13, 1508-1514, doi:10.1890/03-5055.

Zelles, L., Q. Y. Bai, T. Beck, and F. Besse (1992), Signature fatty acids in phospholipids and lipopolysaccharides as indicators of microbial biomass and community structure in agricultural soils, Soil Biol. Biochem., 24 , 317-323, doi:10.1016/0038-0717(92)90191-Y.

Ziegler, S. E., P. M. White, D. C. Wolf, and G. J. Thoma (2005), Tracking the fate and recycling of ${ }^{13} \mathrm{C}$-labeled glucose in soil, Soil Sci., 170, $767-$ 778, doi:10.1097/00010694-200510000-00002.

S. A. Billings, Department of Ecology and Evolutionary Biology, University of Kansas, 2101 Constant Ave., Lawrence, KS 66047, USA.

S. E. Ziegler, Department of Earth Science, Memorial University of Newfoundland, St. John's, NL A1B 3X5, Canada. (sziegler@mun.ca) 